\title{
Is China's Energy Supply Sustainable? New Research Model Based on the Exponential Smoothing and GM(1,1) Methods
}

\author{
Pin $\mathrm{Li}^{1,2}$ and Jinsuo Zhang ${ }^{3, *}$ \\ 1 School of Safety Science and Engineering, Xi'an University of Science and Technology, Xi'an 710054, China; \\ lipin1012@126.com \\ 2 Research Center for Energy Economy and Management, Xi'an University of Science and Technology, \\ Xi'an 710054, China \\ 3 School of Economics and Management, Yan'an University, Yan'an 716000, China \\ * Correspondence: zjs@yau.edu.cn; Tel.: +86-0911-2337799
}

Received: 14 December 2018; Accepted: 10 January 2019; Published: 14 January 2019

\begin{abstract}
Energy supply sustainability is an important issue in the field of energy security. To successfully achieve the goals of sustainable economic and social development and to implement the "Paris Agreement", we need to accurately evaluate and predict the energy supply sustainability of countries or regions. However, it is very difficult to evaluate and predict energy supply sustainability, because it belongs to a complex multi-attribute decision-making problem. This paper proffered a new definition of the energy supply sustainability in China and put forward sixteen indicators for it from the four dimensions of energy availability, economic sustainability, environmental sustainability and technical sustainability. First, the energy supply sustainability index (ESSI) was quantified by a comprehensive evaluation method. Secondly, based on the exponential smoothing and $\operatorname{GM}(1,1)$ prediction models, two ideas were put forward to predict the sustainable level of China's energy supply, enriching the theoretical study of energy security prediction. The study found that: (1) China's energy supply sustainability index changes dynamically; it has an asymmetric " $W$ " trend from 2000 to 2016. The energy supply sustainability level of China is low; it cannot satisfy the Chinese people's need for high-quality eco-energy products or the needs of social sustainable development. The three indicators of reserve and production ratio, production diversity and clean power generation are very important to China's energy supply sustainability. (2) Referring to the accuracy criteria, the Mean absolute percentage error (MAPE) of the Exponential smoothing-GM $(1,1)$ hybrid model for forecasting China's energy supply sustainability is only $2 \%$, and the Root mean square error (RMSE) is 0.0278; therefore, it is suitable for use in the forecasting of the energy supply sustainability level in China. (3) In the short term, from 2017 to 2020, many unsustainable factors remain within China's energy supply, and the sustainable level is level II. In the long term, the sustainable level of China's energy supply will be greatly improved and will increase to 0.8765 by 2030, attaining a sustainable level. However, China remains far behind other countries, with high levels of energy sustainability and energy security in the world.
\end{abstract}

Keywords: energy supply; energy security; sustainability assessment; exponential smoothing; GM(1,1); hybrid forecasting

\section{Introduction}

Climate change is becoming one of the key scientific issues that must be addressed globally, and many scientists attribute climate change to increased carbon dioxide emissions from fossil fuel combustion [1]. According to the International Energy Agency (IEA) [2], the annual global $\mathrm{CO}_{2}$ 
emissions from fossil fuels have increased, from almost 23.6 billion tons of carbon dioxide $\left(\mathrm{GtCO}_{2}\right)$ in the 1990 s to around $32.4 \mathrm{GtCO}_{2}$ in 2014 . Carbon emissions are expected to increase by $50 \%$ between 2014 and 2050, which will result in the global average temperature being $3.2{ }^{\circ} \mathrm{C}$ to $4{ }^{\circ} \mathrm{C}$ higher than the pre-industrial level. These phenomena are the consequences of global warming, which is caused by the massive use of fossil fuels by humans. Fossil fuels and climate change are inextricably linked [3], and a high proportion of carbon-intensive energy causes great damage to the sustainable development of the environment, the economy and society. Since the beginning of the industrial revolution, access to clean, affordable and reliable energy has been the cornerstone of the world's growing prosperity and economic growth. However, energy use in the 21st century must also be sustainable [4]. Energy sustainability has become a key issue of global concern.

The concept of sustainable development has been widely integrated into energy and industrial systems. In 2015, the international community [5] formulated the "The 2030 Agenda for Sustainable Development", which is intended to address global environmental degradation and resource depletion. Among the agenda items, sustainable energy provision and access, one of the central themes of the 2030 Agenda, whose preamble calls for 'universal access to affordable, reliable and sustainable energy,' recognizes that 'social and economic development depends on the sustainable management of our planet's natural resources' [6]. Energy security, environmental sustainability and energy equity are the three core challenges to be met with in achieving the transition to a Low-Carbon Economy [7]. The United States has stricter requirements for energy security; renewable energy, solar energy, and wind energy are all safe and very cheap in the United States. However, not every country has similar policies. China is the world's second largest economy and the world's largest energy producer and carbon dioxide emitter. China's energy is first and foremost affordable, because all rural areas in China have access to electricity. Except for rural areas, which rely on government subsidies, China's electricity is basically affordable, and there are no reports that its citizens cannot afford to pay their electricity bills. Second, China's energy is also available. Compared with the power grids of countries all over the world, China's power grid reliability is very high, and the possibility of interruption is very small; there have been almost no interruptions to the power grid in China. However, China's energy is far from sustainable.

China's energy is not sustainable, first, because the energy supply is not sustainable. According to the BP World Energy Statistical Yearbook 2018 [8], China's energy consumption increased by 3.1\% in 2017, and China has been the country with the largest increase in global energy consumption for 17 consecutive years. However, more than $60 \%$ of the energy supply is coal. In contrast, coal use in the United States is only approximately $15 \%$. This finding means that, as time passes, environmental pollution caused by the energy supply will continue to threaten China's energy security [9]. Energy security is a key driver of current and future energy policies in the world [10]. The Chinese government attaches great importance to this feature. Li Keqiang, Premier of the State Council, at the first meeting of the National Energy Committee in 2014, said that energy supply and security are related to the overall situation of China's modernization. China should actively develop clean energy, improve environmental quality and embark on a clean, efficient, safe and sustainable energy development path. Since 2014, China's coal consumption has declined for three years, and it decreased by $4.7 \%$ year-on-year in 2016 . Thus, can the transformation of the energy supply structure be successful? Can China's energy sustainable development goals be achieved? When will they be achieved? To solve these problems, we need to have a deep understanding of China's history and future sustainable energy supply level. Given this history, this paper accurately evaluates and predicts China's energy supply sustainability to provide a reference for decision-making departments.

\section{Literature Review}

Energy supply sustainability stems from energy security and has become more specific with the growing energy security research. Energy supply security is vital for the whole world [11]. For many years, organizations and scholars have carried out profound and extensive research on this 
issue. Because of the different research backgrounds and objects, the definitions of energy security are also different. Among them, the two most popular concepts are gaining an adequate energy supply at reasonable prices, which was put forward by the International Energy Agency (IEA) [12,13], and the " $4 \mathrm{~A}$ " concept of energy security, which comprises availability, accessibility, affordability and acceptability, and was put forward by the Asia Pacific Energy Research Centre (APERC) [14]. Over the years, scholars, such as Le [15], Sovacool [16], Ren [17] et al., have conducted empirical research based on these two definitions. The definition of energy security is dynamic, and environmental sustainability and energy efficiency are increasingly emphasized by scholars, such as Sovacool [18], Radovanović [19], Ang [20], Zhang [21] et al. Especially considering the proposal of the World Energy Council's energy sustainable development, more and more scholars have taken energy sustainability as the focus of their research. Brown [22] constructed an energy sustainability index (ESI) and conducted practical research, taking the United States as an example. Afgan [23] evaluated the quality of hybrid energy systems, using sustainability assessment methods from the economic, environmental and social perspectives. Tsai [24] established Taiwan's sustainable development indicators (TSDI) system in 2003 and conducted an analysis of energy sustainability from Taiwan's renewable energy production. Kumar [25] evaluated the sustainability of the run of the river (RoR) hydropower projects in hydro-rich regions of India from social, environmental, and economic perspectives. Mainali [26] used the principal component analysis (PCA) method to evaluate the sustainability performance of energy technologies applied in rural electrification. Iddrisu [27] proposed a comprehensive Sustainable Energy Development Index (SEDI) to measure the sustainability of a country's energy system. This article provides a further overview of energy sustainability, as shown in Table 1.

The researches on energy sustainability clearly show that, first, from the research topic, many scholars conduct research on energy sustainability or research energy supply security but consider energy sustainability an important aspect of their research. The authors' research areas include oil, natural gas, coal, water and hybrid energy systems. Second, the research dimension is relatively extensive, involving economic, social, environment, sustainability, technology, hybrid energy systems and many other aspects. In summary, the dimensions are mainly availability, the economy, sustainability, the environment, energy technology and efficiency. Among these topics, energy security and related sustainability issues have, in recent years, begun to garner the focus of scholars. Third, from the research methodology, in the early years, scholars focused on the comprehensive evaluation of regional energy security using a comprehensive evaluation method. In recent years, research methods have become increasingly diversified, from statistical methods to artificial intelligence, and machine learning methods, such as agent, have become more popular among scholars because of the speed and accuracy of their calculations. In summary, the following problems continue to need further study. First, among the research objects, the issue of environmental sustainability has garnered the attention of some scholars. However, their focus is on the sustainability of hybrid energy systems, energy technologies or renewable energy. Energy supply is the core of energy security. Most of the unsustainable problems of energy security stem from the unsustainable supply. Thus, the sustainability of an energy supply is a problem that requires in-depth research. Second, regarding the research methodology, scholars mainly focus on the comprehensive evaluation of energy sustainability or the prediction of individual indicators of energy demand/supply. There are few predictions for multi-criteria decision-making, such as energy supply sustainability.

Energy supply sustainability requires intelligent forecasting algorithms and models. There are five main types of commonly used forecasting techniques: The multiple linear regression analysis, random time series model, exponential smoothing method, adaptive load forecasting model [28], and machine learning method [29]. These techniques can be grouped into two types of models, those based on statistics and those based on artificial intelligence, which are mainly studies on energy forecasting methodology, as shown in Table 2. The first type of model, that based on statistics, which is usually expressed by mathematical equations, automatic regression (AR), moving average (MA), automatic regression moving average (ARMA), automatic regression synthetic moving average 
(ARIMA) and exponential smoothing, belong to the category of statistical modeling [30,31]. The second type of model is based on artificial intelligence as an expert system, the Grey Model (GM), the artificial neural network (ANN), fuzzy logic, support vector regression and the Agent-Oriented Intelligent model [32-34]. These models have significant advantages in relation to prediction and high-precision fitting, and they are widely used in the forecasting of energy price, wind speed and renewable energy [35-37]. However, artificial intelligence models are complex, and they have high requirements in relation to the amount of data. Therefore, this type of model is not necessarily suitable for all prediction studies, such as the multi-indicator decision-making problem. I have creatively carried out the relevant research, proposing a method for predicting the level of energy supply security and mentioning the environmental problems of energy supply, and fortunately published it in this journal of energies [38]. However, it focuses on the level of energy supply security from the perspective of the overall national security concept. In 2001, the European Commission green book, "Towards a European energy supply security strategy," claimed that the European Union's long-term strategy for energy supply security must focus on environmental protection for the well-being of its citizens and the normal functioning of its economy [39]. China is a populous country. It should take into account the equality and sustainability of an energy supply to ensure the sustainable and healthy development of the economic society. Therefore, based on the previous paper, this paper focuses on energy availability, economic sustainability, environmental sustainability and technical sustainability, further studying the sustainability of China's energy supply and further optimizing the evaluation method, taking into account the dynamic change of the indicator weight over time.

However, the forecasting object of this paper is the sustainability of China's energy supply, and there are still great difficulties in forecasting work: (1) Energy sustainability is greatly affected by various uncertain factors, and it is dynamic. Therefore, it is difficult to forecast it. (2) The data selected in this article contain many time series. The time series data are easily affected by external noise and present complex characteristics, such as being nonstationary and random, which makes forecasting more difficult. Sustainable energy development has both short-term goals and long-term goals. Therefore, the forecast of energy supply sustainability must be both short-term and long-term. The exponential smoothing model, based on statistics, considers both the extensibility of sequence development and randomness, which usually performs well in medium- and long-term predictions. This model is widely used for energy demand, energy supply, and solar radiation prediction [40,41]. Compared with ARIMA, LES and the random walk (RW) model, the exponential smoothing model has better performance in short-term prediction $[42,43]$. The GM(1,1) model, based on artificial intelligence, is effective at predicting multifactor variables and provides an error test of model estimation parameters for easy calculation $[44,45]$. Even with a very small sample size, this model continues to have a better predictive power. The GM $(1,1)$ model can achieve a higher prediction accuracy through parameter improvement or combination with other models [46-48]. Through the above analysis, this paper adopts the statistical model exponential smoothing model and the artificial intelligence model GM(1,1) model and attempts to use the combination of these two models to predict China's sustainable energy supply level. In Section 3, we propose the definition and impact indicators of energy supply sustainability and proffer a measurement method for energy supply sustainability. In Section 4, based on the exponential smoothing and $\operatorname{GM}(1,1)$ prediction models, two ideas are put forward to predict the sustainable energy supply level. In Section 5, based on Sections 3 and 4, and using China as an example, the effectiveness of the above methods is further verified. Section 6 concludes the research. 
Table 1. Primary studies on energy sustainability dimensions: indicators and methods.

\begin{tabular}{|c|c|c|c|c|c|c|}
\hline No. & Author & Themes & Dimension & $\begin{array}{c}\text { No. of } \\
\text { Countries }\end{array}$ & $\begin{array}{l}\text { No. of } \\
\text { Indicators }\end{array}$ & Model \\
\hline 1 & Brown [22] & Energy sustainability & Oil security, Electricity reliability, Energy efficiency, Environmental quality & 1 & 12 & \\
\hline 2 & Su [49] & $\begin{array}{l}\text { Energy security, energy supply } \\
\text { network }\end{array}$ & $\begin{array}{l}\text { The production, Refining, consumption, Reserve, and transit sectors, Various external } \\
\text { supply sources }\end{array}$ & 1 & - & $\begin{array}{l}\text { Ecological network analysis } \\
\text { (ENA) }\end{array}$ \\
\hline 3 & Chester [50] & Energy security, Security of supply & Availability, Adequacy of capacity, Affordability, Sustainability & - & - & Reviews \\
\hline 4 & Sovacool [18] & Energy security, Energy supply & Availability, Affordability, Technology development, Sustainability and regulation & 10 & 320 & Subjective scoring \\
\hline 5 & Carrera [51] & Sustainability energy technologies & $\begin{array}{l}\text { Security and reliability of energy provision, Political stability and legitimacy, Social and } \\
\text { individual risks, Quality of life }\end{array}$ & 4 & 9 & Expert interviews \\
\hline 6 & Begi [52] & $\begin{array}{l}\text { Multi-criteria sustainability } \\
\text { assessment }\end{array}$ & $\begin{array}{l}\text { Resource indicator (RI), Environment indicator (EI), Economic indicator (EI), Social } \\
\text { indicator (SI) }\end{array}$ & 2 & 14 & $\begin{array}{l}\text { Multi-criteria decision-making } \\
\text { methods }\end{array}$ \\
\hline 7 & Matsumoto [11] & Energy security & $\begin{array}{l}\text { Energy availability, Infrastructure, Energy prices, Societal effect, Environment, } \\
\text { Governance, Energy efficiency }\end{array}$ & 29 & 7 & $\begin{array}{l}\text { Time-series clustering, } \\
\text { Shannon } \\
\text { Wiener diversity index }\end{array}$ \\
\hline 8 & Santoyo [53] & $\begin{array}{l}\text { Sustainability assessment of energy } \\
\text { systems }\end{array}$ & Environmental indicators, Economic indicators, Social indicators & 1 & 17 & $\begin{array}{l}\text { Multi-criteria decision analysis } \\
\text { (MCDA) }\end{array}$ \\
\hline $\begin{array}{c}9 \\
10\end{array}$ & $\begin{array}{c}\text { Tsai }[24] \\
\text { Krey [54] }\end{array}$ & Energy sustainability & $\begin{array}{l}\text { Economic, Environmental } \\
\text { Security of supply, Climate change mitigation, Air-pollution reduction, }\end{array}$ & $\begin{array}{l}1 \\
1\end{array}$ & $\begin{array}{l}5 \\
3\end{array}$ & Pressure-State Response (PSR) \\
\hline 11 & $\begin{array}{l}\text { Krey [54] } \\
\text { Stefano [55] }\end{array}$ & $\begin{array}{l}\text { Energy sustainability } \\
\text { Sustainability assessment }\end{array}$ & $\begin{array}{l}\text { Security of supply, Climate change mitigation, Air-pollution reduction, } \\
\text { technical, Economic and energetic }\end{array}$ & 1 & $\begin{array}{l}3 \\
-\end{array}$ & $\begin{array}{l}\text { MESSAGE } \\
\text { Analysis of variance (ANOVA }\end{array}$ \\
\hline 12 & Mondal [56] & Renewable energy, Sustainability & Solar energy, Wind energy, Biomass potential, Hydro resource potential & 1 & - & $\begin{array}{l}\text { GIS-based Geospatial Toolkit } \\
\text { (GsT), Hybrid System }\end{array}$ \\
\hline 13 & Zhang [21] & Provincial energy security & $\begin{array}{l}\text { Availability and diversity, Affordability and equality, Technology and efficiency, } \\
\text { Environmental sustainability, Governance and innovation }\end{array}$ & 1 & - & $\begin{array}{l}\text { Multicriteria Decision-Making } \\
\text { methods }\end{array}$ \\
\hline 14 & Duan [57] & Energy investment assessment & $\begin{array}{l}\text { Political risk, Economic foundation, Investment environment, Resource potential, } \\
\text { Environmental constraint }\end{array}$ & 50 & 36 & $\begin{array}{l}\text { A fuzzy integrated evaluation } \\
\text { model }\end{array}$ \\
\hline 15 & Narula [58] & Sustainable energy security & Availability, Affordability (economic dimension), Efficiency, Acceptability & 15 & - & $\begin{array}{l}\text { PCA (principal component } \\
\text { analysis), Weighting and } \\
\text { Aggregation }\end{array}$ \\
\hline 16 & Sovacool [59] & $\begin{array}{l}\text { Sustainable development, Energy } \\
\text { security }\end{array}$ & Security, Poverty, Development, Fiscal responsibility, Governance & - & - & $\begin{array}{l}\text { Regression and comparative } \\
\text { country analyses }\end{array}$ \\
\hline
\end{tabular}


Table 2. Review of energy forecasting methodology.

\begin{tabular}{|c|c|c|c|c|c|c|c|c|}
\hline No. & Source & Study Field & Country & Forecasting Model & Single/Combination & Forecasting Scope & Data Used & Forecasted Years \\
\hline 1 & Bacher [60] & Solar power & Denmark & ARX & Single & Monthly & 2006 & Up to $2 \mathrm{~h}$ ahead \\
\hline 2 & Mellit [61] & Solar irradiance & Italy & ANN, MLP & Single & Days & 2009 & $24 \mathrm{~h}$ ahead of solar irradiance \\
\hline 3 & Pinson [62] & Wind power & Jutland & $\begin{array}{c}\text { Non-parametric Probabilistic } \\
\text { Forecasts }\end{array}$ & Single & Hours & 2001-2003 & $24 \mathrm{~h}$ ahead \\
\hline 4 & Pedro [63] & Solar energy & California & ARIMA, KNNs, ANS, GAS, ANN & Single & Hours & 2009-2011 & $1 \mathrm{~h}$ and $2 \mathrm{~h}$ \\
\hline 5 & Lorenz [64] & $\begin{array}{l}\text { Photovoltaic } \\
\text { (PV) systems }\end{array}$ & Germany & $\begin{array}{l}\text { European Centre for Medium-Range } \\
\text { Weather Forecasts (ECMWF) }\end{array}$ & Combination & - & 2006 & Predictions up to $72 \mathrm{~h}$ \\
\hline 6 & $\begin{array}{l}\text { Bludszuweit } \\
{[65]}\end{array}$ & Wind power & - & Beta pdf & Single & Mins & - & Up to $24 \mathrm{~h}$ ahead \\
\hline 7 & Ekonomou [66] & $\begin{array}{c}\text { Energy } \\
\text { consumption }\end{array}$ & Greek & $\begin{array}{l}\text { Multilayer perceptron model MLP } \\
\text { ANN }\end{array}$ & Single & Yearly & 1992-2004 & 2005-2015 \\
\hline 8 & $\operatorname{Tan}[67]$ & Electricity price & $\begin{array}{l}\text { Spanish and } \\
\text { PJM electricity } \\
\text { markets }\end{array}$ & ARIMA and GARCH & Combination & Hours & 2002,2006 & 2002, 2006 \\
\hline 9 & Wang [68] & Real oil prices & Ponolai Chino & $\begin{array}{l}\text { Time-varying parameter (TVP) } \\
\text { complementary ensemble Empirical }\end{array}$ & Combination & - & 1986-2015 & $1 \mathrm{~h}$ to $12 \mathrm{~h}$ ahead \\
\hline 10 & $\mathrm{Du}[69]$ & $\begin{array}{l}\text { Electrical power } \\
\text { system }\end{array}$ & $\begin{array}{l}\text { Penglai, China, } \\
\text { Australia and } \\
\text { Singapore }\end{array}$ & $\begin{array}{l}\text { mode decomposition (CEEMD), } \\
\text { LSSVM, Whale optimization } \\
\text { algorithm (WOA) }\end{array}$ & Combination & Mins & 2011-2015 & 30 min ahead \\
\hline 11 & Ziel [70] & Electricity price & $\begin{array}{l}\text { European } \\
\text { Saudi Arabia, }\end{array}$ & periodic VAR-TARCH & Combination & Monthly & 2012 & $1 \mathrm{~h}$ ahead \\
\hline 12 & Matsumoto [71] & ACEGES model & $\begin{array}{l}\text { Iran, Canada, } \\
\text { Venezuela }\end{array}$ & Unconventional oil & Single & Yearly & $2020-2100$ & - \\
\hline 13 & Prema [72] & Solar power & India & $\begin{array}{l}\text { Moving average model, Exponential } \\
\text { smoothing models }\end{array}$ & Combination & Monthly & 2012-2013 & 1 week ahead \\
\hline 14 & Dong [42] & Solar irradiance & $\begin{array}{l}\text { Singapore, } \\
\text { Colorado, USA }\end{array}$ & Exponential smoothing & Single & Mins & 2010-2011 & 5 min ahead \\
\hline 15 & Trapero [73] & Solar irradiance & Spanish & $\begin{array}{l}\text { Persistence model, Seasonal } \\
\text { persistence model, Exponential } \\
\text { smoothing, ARIMA model }\end{array}$ & Combination & Hours & 2009-2011 & $24 \mathrm{~h}$ ahead \\
\hline 16 & Meng [74] & $\mathrm{CO}_{2}$ emissions & China & $\begin{array}{l}\text { The traditional linear model, } \\
\mathrm{GM}(1,1) \text {, and the hybrid mode }\end{array}$ & Combination & Yearly & 1982-1991 & 1992-2011 \\
\hline 17 & Xiong [75] & $\begin{array}{l}\text { Energy } \\
\text { production, } \\
\text { Energy } \\
\text { consumption }\end{array}$ & Iran, Argentin & Novel GM(1,1) & Single & Yearly & 2003-2009 & 2010-2012 \\
\hline 18 & Wang [47] & $\begin{array}{l}\text { Electricity } \\
\text { consumption }\end{array}$ & China & Seasonal GM(1,1) & Single & Yearly & 2010-2016 & 2017-2020 \\
\hline 19 & Steinert $[70]$ & Electricity Price & $\begin{array}{l}\text { Germany and } \\
\text { Austria }\end{array}$ & AR24-X model & Combination & Daily & 2011-2014 & 1 day ahead \\
\hline
\end{tabular}




\section{Conceptualizing and Measuring Energy Supply Sustainability}

Energy supply sustainability is affected greatly by various uncertain factors, and it is dynamic in nature. So far, there is no uniform standard to measure it. Research shows that public opinion of energy security reflects geographic variation, and the national energy security index can explain this difference [76]. Referring to the "International Index of Energy Security Risk" [77,78], EU Standards for Energy Security of Supply [79] and the "Energy Sustainability Index" proposed by the World Energy Council [19], and according to the United Nations' requirements of sustainable energy development, we have proposed a new definition for the energy supply sustainability of China. This definition conceptualizes energy supply sustainability in the four dimensions of energy availability, economic sustainability, environmental sustainability and technical sustainability. In addition, the measurement method of energy supply sustainability index (ESSI) is put forward.

\subsection{Definition and Intent of Energy Supply Sustainability}

Since 1990 "sustainable development" and "resources" have been the two most commonly used keywords in the scientific literature related to the Green Economy (GE) concept [80]. They involve reducing negative health and environmental impacts, while increasing energy availability, affordability, safety and efficiency [81]. Energy policy directives from various industrialized countries indicate that the process of entering this new era includes common interests, such as improving energy productivity, ensuring reliable supply, energy security and diversity, economic efficiency, support for research and development and regional partnerships for the development of more advanced technologies [82]. In 2004, the United Nations Development Program (UNDP) introduced sustainable energy security concepts in the Global Energy Assessment report, with an emphasis on environmental sustainability. In 2010, the World Energy Council [19] launched the Energy Architecture Performance Index (EAPI), which focused on energy and climate policies. In the second year, the index was revised in the Energy Sustainability Index 2011, while the methodology and the approach did not change. The World Energy Council (2013) [83] noted that energy security, energy equity, and environmental sustainability constitute the 'energy trilemma' of the world. Thus, the world energy sustainable development index was proffered. Sovacool [76] noted that the concept of energy security is multifaceted and can cover a number of apparently distinct energy and climate-related risks. Sustainability can be defined as ensuring that the development of an energy system is most effectively synchronized with a country's natural endowments, technological capabilities, social expectations and economic development profiles [84]. David [85] noted that energy supply is dynamic; with the emergence of climate change, local air pollution, acid rain and other issues, its definition should reflect these emerging risk factors to guide countries' energy policies. Regarding energy sustainability, Kleber [86] believed that energy sustainability refers to the extent to which an energy supply can be extended to reduce the use-related environment. Bringezu [87] conceptually intersected the Sustainable Development Goals (SDGs) with resource use "challenges and risks". Laldjebaev [88] conceptualizes energy security as a low vulnerability of vital energy systems and the sustained provision of modern energy services. Based on the research of the above organizations and scholars, this article maintains that the energy supply is the starting point of energy security and the core of energy security. First, the sustainability of energy systems must be addressed from the supply side to ensure that the supplied energy does not affect the environment during production and that its use can promote sustainable economic and social development. This article defines energy supply sustainability as: energy supply sustainability exceeding an energy supply. Sustainability is an important function of an energy security system. Based on a sustainable and sufficient energy supply, energy supply sustainability focuses more on the fairness of the energy supply and environmental sustainability. It is necessary, not only to ensure that sufficient energy is provided to all people and enterprises at reasonable prices in the short and long term, but also to ensure that the supply of energy in the process of usage will not cause damage to society and the environment or to minimize the degree of damage. Ultimately, the sustainable development of the energy supply and the economy, society and the environment will be realized. 
According to this definition and referencing the research results of scholars (Table 1), the connotation of energy supply sustainability can be understood as follows:

(1) Energy availability: Availability refers to the possibility of obtaining energy supplies geographically. Specifically, availability refers to obtaining a sufficient energy supply from local resources to promote energy production and a diversified supply. Fossil fuels are constrained by declining production and are being used in order of availability, and the cheapest energy use is ranked first [89]. This means that, before fossil fuels are eventually exhausted, either alternative or renewable sources of energy are available to ensure an adequate supply of energy or there is another fossil fuel to replace those that are less acceptable or more expensive [90]. In other words, energy reserves and diverse energy resources are key factors affecting energy supply sustainability [91]. Strategic petroleum reserve (SPR) and alternative fuels are both important for energy security [92].

(2) Economic sustainability: This dimension evaluates whether the energy supply is cost effective and affordable. On the one hand, economic sustainability refers to reasonable and stable energy prices [93], because energy prices determine the affordability of energy supply. Fluctuations in fossil fuel prices may lead to energy supply problems and influence decision-makers' capacity to plan [94]. If the supply of energy is too expensive, society cannot consume it. On the other hand, economic sustainability also requires that the supplied energy is not just physically available but actually accessible to society, because they can afford to consume it. Personal payment ability also directly affects the affordability of the energy supply. The two complement each other to ensure the sustainability of the supply system [27].

(3) Environmental sustainability: Energy and the environment are closely related. The sustainability of an energy supply requires the coordinated development of energy supply and the environment. Environmental sustainability is the basic premise of sustainable energy supply. Fossil fuels have adverse environmental impacts during mining and use, especially environmental pollution caused by burning, even if clean energy causes damage to the environment [95]. The European Commission [96] stresses the importance of the environment and sustainability to energy security. Environmental protection is the focus of the international community. It is necessary to focus on the environmental sustainability of an energy supply, that is, to form a spatial pattern that conserves resources, protects the environment and provides a safer and cleaner energy supply to society.

(4) Technical Sustainability: Access to sustainable and modern energy for the people requires improvement indicators of energy efficiency and carbon saving from energy technologies [97]. This is the supply side of the cycle, which captures the ability of the energy supply system to reliably and effectively meet the present and future needs of society. The efficiency of a sustainable energy supply includes both the efficiency, in an economic sense, and the profit and loss of natural resources and the environment, that is, the minimum energy consumption and energy loss under the same energy supply service, involving the construction of energy infrastructure, the development of energy technologies and the improvement of energy efficiency. The level of energy efficiency can reflect the level of national energy technology, and energy consumption can be reduced effectively by improving energy efficiency. Energy technology is an important support for achieving a sustainable energy supply [98-100]. Improving energy technologies and efficiency can help to reduce energy demand and improve energy supply sustainability in order to meet current and future energy demands.

\subsection{Energy Supply Sustainability Indicators}

Indicators are generally considered to be parameters that provide information regarding the state of the system. Since sustainability refers to the long-term evolution of a complex system, there are many uncertainties in the evolution process, and the purpose of indicators is to make decision-making less risky. Sustainability indicators and composite indexes are gradually used as powerful tools for communicating sustainability performance to policy makers and the general public [101]. The energy supply system is a complex system that is rapidly affected by many uncertainties and changes. Therefore, it is very important to select scientific evaluation objects and indicators for this system. 
According to the definition and connotation of energy supply sustainability, shown in Section 3.1, which are based on the research results of relevant scholars (Table 1), according to the design principle that the number of indicators should not be excessive (no more than 20) [20], and considering the data availability, the energy supply sustainability indexes for China were determined from the following four first-grade indexes: energy availability, economic sustainability, environmental sustainability and technical sustainability. These dimensions are shown in Table 3. The proposed framework constitutes 16 indicators, which are as follows.

Table 3. Indicators for the energy supply sustainability index.

\begin{tabular}{|c|c|c|c|c|}
\hline Dimensions & Indicators & Equation & Variable Description & Indicator Source \\
\hline \multirow{5}{*}{ Energy availability } & $\begin{array}{c}\text { Reserve and production } \\
\text { ratio }\left(\mathrm{X}_{1}\right)\end{array}$ & $\sum r_{i} p_{i}$ & $\begin{array}{l}r_{i} \text {-Reserve and production ratio of energy i } \\
p_{i} \text {-Proportion of energy i produced in energy } \\
\text { sources' production }\end{array}$ & {$[16,18,102,103]$} \\
\hline & $\begin{array}{l}\text { Production diversity index } \\
\qquad\left(\mathrm{X}_{2}\right)\end{array}$ & $\sqrt{\sum_{i=1}^{n} p_{i}^{2}}$ & $\begin{array}{l}p_{i} \text {-Proportion of energy i produced in energy } \\
\text { sources' production }\end{array}$ & {$[20,102,104-106]$} \\
\hline & Energy dependence $\left(X_{3}\right)$ & $\frac{\mathrm{Q}_{\text {eit }}}{\mathrm{Q}_{\text {est }}}$ & $\begin{array}{l}\mathrm{Q}_{e s t}-\mathrm{TPES} \\
\mathrm{Q}_{\text {eit }} \text {-Energy dependence }\end{array}$ & {$[16,77,102,107]$} \\
\hline & TPEC per capita $\left(\mathrm{X}_{4}\right)$ & $\frac{\mathrm{Q}_{\text {eit }}}{T_{p}}$ & $\mathrm{Q}_{e s t}$-TPES, $T_{p}$ - total number of populations & {$[9,83,107]$} \\
\hline & Market liquidity $\left(\mathrm{X}_{5}\right)$ & $\frac{I_{m c}}{I_{m w}}$ & $\begin{array}{l}\text { Imc-Domestic oil imports, Imw-Total world } \\
\text { oil imports }\end{array}$ & {$[18,102,107-109]$} \\
\hline \multirow[t]{2}{*}{$\begin{array}{c}\text { Economic } \\
\text { sustainability }\end{array}$} & $\begin{array}{l}\text { The economic vulnerability } \\
\text { index }\left(\mathrm{X}_{6}\right)\end{array}$ & $\begin{array}{l}\mathrm{EVI}=\frac{C_{o}}{G D P}=P_{o} \times \\
\frac{Q_{o i p}}{Q_{o i t}} \times \frac{Q_{o i t}}{Q_{e c t}} \times \frac{Q_{e c t}}{G D P}\end{array}$ & $\begin{array}{l}\text { EVI-oil import economic vulnerability index; } \\
\text { Co-crude oil import cost; Qoip—-total crude oil } \\
\text { import, Qoit—crude oil consumption amount, } \\
\text { Qect-amount of energy consumption, } \\
\text { Po-Brent spot price. }\end{array}$ & {$[103,110]$} \\
\hline & Energy price index $\left(\mathrm{X}_{7}\right)$ & - & $\begin{array}{l}\text { Purchase price index of fuel and power by } \\
\text { industrial producers }\end{array}$ & {$[18,20,77,102,108,111]$} \\
\hline \multirow{6}{*}{$\begin{array}{l}\text { Environment } \\
\text { sustainability }\end{array}$} & GDP per capita $\left(X_{8}\right)$ & $\frac{G D P}{T_{p}}$ & $T_{p}$-Total number of populations & {$[19,109,112]$} \\
\hline & Water pollution $\left(\mathrm{X}_{9}\right)$ & $\frac{\mathrm{E}_{\text {wat }}^{\text {pat }}}{T_{p}}$ & $\mathrm{E}_{\text {wat }}$-Total waste water emissions & {$[16,18,20,108,113,114]$} \\
\hline & $\begin{array}{l}\text { Sulfur dioxide emissions per } \\
\text { capita }\left(\mathrm{X}_{10}\right)\end{array}$ & $\frac{E_{\mathrm{so}_{2}}}{T_{p}}$ & $E_{\mathrm{SO}_{2}}$-Total sulfur dioxide emissions & {$[20,77,104,107,111,113]$} \\
\hline & $\begin{array}{l}\text { NOx emissions per capita } \\
\left(\mathrm{X}_{11}\right)\end{array}$ & $\frac{E_{N O_{x}}}{T_{p}}$ & $E_{N}$-Total NOx emissions & {$[18,77,105,113]$} \\
\hline & Land use $\left(\mathrm{X}_{12}\right)$ & - & Forest coverage & {$[16,18,20,108,113,114]$} \\
\hline & $\begin{array}{l}\text { Clean power generation } \\
\qquad\left(\mathrm{X}_{13}\right)\end{array}$ & - & Generation in power-generation capacity & {$[9,19,80,103,115]$} \\
\hline \multirow{3}{*}{$\begin{array}{c}\text { Technical } \\
\text { sustainability }\end{array}$} & Domestic infrastructure & - & Investment in fixed assets of energy industry & {$[110,116]$} \\
\hline & $\begin{array}{l}\text { Electricity distribution } \\
\text { efficiency }\left(X_{15}\right)\end{array}$ & $\frac{E_{\text {dis }}}{E_{\text {tot }}}$ & $\begin{array}{l}E_{d i s} \text {-Electricity distribution losses, } \\
E_{\text {tot }} \text {-Total electricity generation }\end{array}$ & {$[16,20,77,107,117]$} \\
\hline & Energy efficiency $\left(\mathrm{X}_{16}\right)$ & $\mathrm{GDP} / \mathrm{Ec}$ & Ec-Total energy consumption & {$[18,20,104,107,117]$} \\
\hline
\end{tabular}

\subsection{Evaluation Methodology}

\subsubsection{Indicator Normalization}

To ensure comparability, the original data of the indicators should be normalized. There are many different types of methods for data normalization. Ang provides us with a comprehensive summary of the data normalization methods [20]. Referring in this paper to Narula et al. [118], indicators of the energy supply system are normalized by the Min-max normalization method, in which each indicator is transformed using the following equation. Indicators can be categorized into two types: the first type constitutes indicators that have a positive impact on ESSI, which can be normalized from Equation (1), and the second type constitutes those indicators that have a negative impact on ESSI, which can be normalized from Equation (2):

$$
\begin{aligned}
x_{i k}^{\prime} & =\frac{x_{i k}-\min \left(x_{i k}\right)}{\max \left(x_{i k}\right)-\min \left(x_{i k}\right)} \\
x_{i k}^{\prime} & =\frac{\max \left(x_{i k}\right)-x_{i k}}{\max \left(x_{i k}\right)-\min \left(x_{i k}\right)}
\end{aligned}
$$

where $x_{i k}^{\prime}$ is the indicator $\mathrm{i}$ in the year $\mathrm{k}$, after normalization. $x_{i k}$ is the value of indicator $\mathrm{i}$ in the year $k$, before normalization, $k=1,2, \ldots, \mathrm{t}, i=1,2, \ldots, \mathrm{m}$. 


\subsubsection{Weighting and Aggregation}

Energy supply sustainability evaluation is a typical issue involving multiple indicators. Before evaluation, the weights of these indicators need to be determined. First, the objectivity and rationality of each index weight will greatly affect the final evaluation results. Currently, there are many methods for determining the weight of indicators, which can, according to different data sources, be approximately divided into three categories when calculating the weight: subjective weighting, objective weighting and synthetic weighting [119]. The commonly used subjective weighting methods include: The Delphi method and the analytic hierarchy process (AHP) method. Because the judgment matrix of this kind of method is determined by expert experience, it is difficult to exclude the influence of individual factors on the index weight. The objective weighting methods include the entropy method and principal component analysis. The entropy method (EM) is a commonly used objective weighting method. This method directly uses the inherent information of the evaluation indicators to empower the indicators and, to an extent, avoids the bias caused by subjective factors [120]. After normalizing the indicators, the steps for calculating the weight of the index by the entropy method are shown below:

First: The decision matrix, $\mathrm{X}=\left\{x_{i k}^{\prime}, i=1,2, \ldots, m ; k=1,2, \ldots, t\right\}$, is normalized for each criterion $C_{i}(i=1,2, \ldots, m)$. The normalized values $s_{i k}$ are calculated by Equation (3):

$$
s_{i k}=x_{i k}^{\prime} / \sum_{t=1}^{n} x_{i k}^{\prime}
$$

Secondly: The entropy $\mathrm{Hi}$ for each criterion $C_{i}$ is calculated by Equation (4):

$$
H_{i}=-v \sum_{t=1}^{n} s_{i k} \ln \left(s_{i k}\right), v \text { is a constant, let } v=1 / \ln (n), \alpha_{i} \geq 0
$$

Thirdly: The degree of divergence $D I V_{i}$ for the intrinsic information in each criterion $C_{i}$ is calculated by Equation (5):

$$
D I V_{i}=1-H_{i}
$$

Fourthly: The entropy weight $w_{i}$ for each criterion $C_{i}$ is calculated by Equation (6):

$$
w_{i}=D I V_{i} / \sum_{i=1}^{m} D I V_{i}
$$

Aggregation is the most commonly used method in measuring energy security; it involves combining the weighted indicators into a composite index. Approximately $83 \%$ of the energy security indexes use this method to aggregate their indicators. Among them, the additive aggregation method, by which the indicators are first multiplied by the weights assigned, then added together to get the index, is most commonly used [77,121]. After the weight is calculated, the ESSI is constructed using the aggregation methods as follows:

$$
\operatorname{ESSI}_{k}=\sum_{i=1}^{m}\left(x_{i k} \times w_{i}\right)
$$

where $E S S I_{k}$ is the energy supply sustainability index of year $k, x_{i k}$ is the normalized value of indicator $i$ in the year $k$, and $w_{i}$ is the weight of indicator $i$.

\subsubsection{Evaluation Criterion}

The ESSI reflects a country or region's energy supply sustainability level, the value range of ESSI is $[0,1]$. The corresponding energy supply sustainability level was divided into five grades by reference to Liu [122], and its step length was 0.2 , which is clearly shown in Table 4. 
Table 4. Sustainable energy supply level table.

\begin{tabular}{ccl}
\hline Sustainable Level & Score & \multicolumn{1}{c}{ Sustainable Characteristics } \\
\hline I & $0.8-1$ & There were a few unsustainable factors, but overall it was in a sustainable state. \\
II & $0.6-0.8$ & There were some unsustainable factors; however, overall, it was in a basically sustainable state. \\
III & $0.4-0.6$ & There were many unsustainable factors, and overall, it was in a weakly sustainable state. \\
IV & $0.2-0.4$ & The sustainable factor had either been close to or exceeded half, and overall, it was not in \\
V & $0-0.2$ & a sustainable state. \\
\end{tabular}

\section{Forecasting Methodology}

\subsection{Forecasting Principles and Processes}

Based on the exponential smoothing model, the $\operatorname{GM}(1,1)$ model and the exponential smoothing-GM(1,1) hybrid model, this paper put forward two experimental schemes to forecast the sustainable level of China's energy supply, as shown in Figure 1, which could advance the energy security theory.

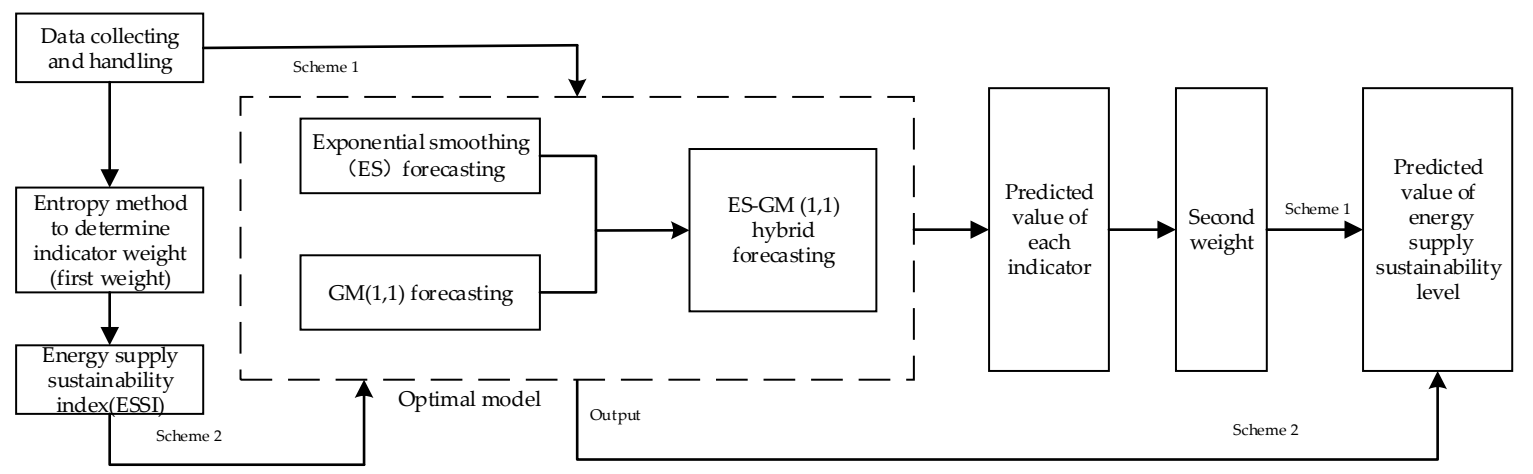

Figure 1. Forecasting principles and processes for energy supply sustainability.

(1) The first scheme: Calculate the predicted value of the energy supply sustainability index ESSI ${ }_{1}^{*}$ by weighing the predicted value of each indicator. The specific process is as follows:

Step 1: Forecasting by the exponential smoothing method.

First, calculate the ESSI of the sample interval, according to the comprehensive evaluation method in Section 3.3, based on the sample observations. We build the time series $x_{i k}$ according to the annual distribution of ESSI and its influencing factors. We then test the stationary and white noise of the time series using the difference method.

Then, we perform the order selection for the matrix. In determining ESSI and its influencing factors' optimal smoothing times based on the BIC matrix, we obtain the optimal exponential smoothing model for ESSI and its influencing factors and forecast their observations. We let $\hat{x}_{i k}^{e s}$ refer to the forecast value of each time series in the year $k$.

Step 2: Forecasting by the $\mathrm{GM}(1,1)$ method.

We write a GM(1,1) function and call to the function. Then, ESSI and its influencing factors are regarded as independent variables. We categorize these variables as the training set and the test set, then we obtain a forecasted value of ESSI and its influencing factors. In this model, we let $\hat{x}_{i k}^{g m}$ refer to the forecast value of each time series in the year $k$.

Step 3: Forecasting by the exponential smoothing-GM(1,1) hybrid model.

Based on the predicted values of observations in step 1 and step 2, we adopt the grid searching method, utilizing minimum errors as the objective. Then, we obtain the optimal weight of the 
exponential smoothing model and GM(1,1) model. Therefore, we obtain the optimal exponential smoothing-GM(1,1) hybrid model as:

$$
\hat{x}_{i k}=p \hat{x}_{i k}^{e s}+(1-p) \hat{x}_{i k}^{g m}
$$

We predict the observations of ESSI again using the exponential smoothing-GM $(1,1)$ hybrid model. The results of ESSI forecasted by the three models are analyzed to select the optimal forecasting model. The choice of the model has a minimum error to improve the prediction accuracy of the prediction model.

Step 4: Using the ESSI and its influencing factors' observations as the test set, and using the chosen model whose deformation error is the lowest, we obtain the forecasted value of ESSI and its influencing factors $\hat{x}_{i k}$. Then, based on the entropy method, shown in Section 3.3.2, we obtain the second weight of each indicator. Finally, based on the comprehensive evaluation method in Section 3.3, we obtain the forecasted value of energy supply sustainability index $\left(E S S I_{1}^{*}\right)$ as follows:

$$
\operatorname{ESSI}_{1}^{*}=\sum_{i=m}^{n} \hat{x}_{i k} \times v_{i}
$$

(2) The second scheme: Forecast $E S S I_{2}^{*}$ directly from ESSI.

First, we calculate the ESSI based on the sample observations. Then, we utilize the ESSI as a time series, according to the optimal model screened by approach 1. Running its program directly, we obtain the forecasted value of the energy supply sustainability index $\left(E S S I_{1}^{*}\right)$ directly.

\subsection{Forecasting Methodology}

\subsubsection{Exponential Smoothing Model}

Exponential smoothing is a kind of moving average (MA) method, which is a class of methods that imply exponentially decreasing weights as observations age. This method is characterized by the assigning of a different weight to different past observations, that is, the weights of the recent observations are larger than those of the older observations. In exponential smoothing, one or more smoothing parameters need to be explicitly determined, and these choices determine the weight assigned to the observed value [123].

The fundamental formulas of exponential smoothing method are:

$$
s_{k}=\alpha x_{k}+(1-\alpha) s_{k-1}
$$

$s_{k}$-smooth value of the variable that is the next forecast value of the variable

$x_{k-1}$-present actual value of the variable

$s_{k-1}$ - present forecast value of the variable

$\alpha$-a constant between 0 and 1

Depending on the different smoothing times, the exponential smoothing method can be classified into three types: single exponential smoothing (SES), double exponential smoothing (DES) and triple exponential smoothing (TES). Referencing the principle of the exponential smoothing method and the basic steps of the three categories of the exponential smoothing method, this paper set the energy supply sustainability model as follows:

(1) The SES model for energy supply sustainability.

If the energy supply sustainability index and its influencing factors are simple data with no trend or seasonal component, the SES model is the best choice. The SES model provides an option for placing exponentially decreasing values of weights on past values of the variable to perform the forecast, 
the immediately recent values having more weight. The equation for the SES forecasting model is given by Equation (11):

$$
\widehat{x_{i(k+1)}}=\alpha x_{i k}+(1-\alpha) \hat{i_{i k}}
$$

$\widehat{x_{i(k+1)}}$-forecast value of variable $i$ in the next year, that is, the smooth value of the variable this year. $x_{i k}$-current actual value of the variable.

$\hat{x_{i k}}$ - current forecast value of the variable, that is, the smooth value of the variable last year.

From Equation (11), it can be observed that the prediction of the future value depends on the present value and the present value obtained from the past value. Obviously, it is an auto recursive process that can be represented as it is shown in Equation (12):

$$
\widehat{x_{i(k+1)}}=\alpha x_{i k}+\alpha(1-\alpha) x_{i(k-1)}+\alpha(1-\alpha)^{2} x_{i(k-2)}+\ldots+\alpha(1-\alpha)^{k-1} x_{i 1}+(1-\alpha)^{k} \widehat{x_{i k}}
$$

From Equation (12), it can clearly be observed that the weight of the past values of variables decreases exponentially. Therefore, this method is called the exponential smoothing method. Here, compared with other predictions, the recent past value has more bearing on the forecast.

(2) The DES model for energy supply sustainability.

When a linear trend appears in the variation of a time series an obvious lag deviation remains in the forecasting by the SES method. It is necessary to correct this deviation. The revised method conducts DES on the basis of the single exponential smoothing. DES is a feasible alternative to the derivative free motion model predictor based on the Kalman filter. DES uses a simple linear regression equation to establish a time series, in which the y-intercept and slope slowly change over time [124]. For these parameters, which decay exponentially over time, unequal weighting is applied. Therefore, newer observations obtain a higher weight than older ones. The degree of exponential decay is determined by the parameter, $\alpha \in[0,1)$.

The formulas of the double exponential smoothing method are:

$$
s_{i k}^{(2)}=\alpha s_{i k}^{1}+(1-\alpha) s_{i(k-1)}^{2}
$$

where:

$s_{i k}^{2}$-double exponential smoothing value of the variable $i$ in the year $k$

$s_{i k}^{1}$-smooth value of the variable $\mathrm{i}$ in the year $k$

$s_{i(k-1)}^{2}$-double exponential smoothing value of the variable i in the year $k-1$

The equation for the double exponential smoothing forecasting model for energy supply sustainability forecasting is given by Equation (14):

$$
\begin{gathered}
\widehat{\mathrm{x}_{\mathrm{i}(k+T)}}=\alpha_{\mathrm{ik}}+b_{i k} T \\
\alpha_{i k}=2 s_{i k}^{(1)}-s_{i k}^{(2)} \\
b_{i k}=\frac{\alpha}{1-\alpha}\left(s_{i k}^{(1)}-s_{i k}^{(2)}\right)
\end{gathered}
$$

(3) The TES model for energy supply sustainability.

The TES method is used when the data show trend and seasonality. TES is conducted on the basis of DES. The formulas of the TES method are:

$$
\mathrm{s}_{i k}^{(3)}=\alpha s_{i k}^{(2)}+(1-\alpha) s_{i(k-1)}^{3}
$$


The equation for the TES forecasting model for energy supply sustainability forecasting is given by Equation (18):

$$
\begin{gathered}
\widehat{\mathrm{x}_{i(k+T)}}=\alpha_{i k}+b_{i k} T+c_{i k} T^{2} \\
\text { Where, } \alpha_{i k}=3 s_{i k}^{(1)}-3 s_{i k}^{(2)}+s_{i k}^{(3)} \\
b_{i k}=\frac{\alpha}{2(1-\alpha)^{2}}\left[(6-5 \alpha) s_{i k}^{(1)}-2(5-4 \alpha) s_{i k}^{(2)}+(4-3 \alpha) s_{i k}^{(3)}\right] \\
c_{i k}=\frac{\alpha^{2}}{2(1-\alpha)^{2}}\left[s_{i k}^{(1)}-2 s_{i k}^{(2)}+s_{i k}^{(3)}\right]
\end{gathered}
$$

\subsection{2. $\mathrm{GM}(1,1)$ Model}

Grey system theory is an important method for studying discrete data sequences with small samples and incomplete information [47]. By fully exploiting and utilizing explicit and implicit information in existing data, the randomness that exists in the sequence is gradually diminished. In this way, the laws governing system changes are generated and can be used to study future time distributions at specific time intervals. We set the time series of ESSI and its influencing factors as $X_{i}^{(0)}=\left\{X_{i}^{(0)}, i=1,2, \ldots, m\right\}$, which are non-negative origin data serials of a prediction object. To build GM(1,1) modeling, we must first conduct a first-order accumulation generation on the original data series as:

$$
\mathrm{X}_{i}^{(1)}=\left\{\mathrm{X}_{i}^{(1)}(k), k=1,2, \ldots, t\right\}
$$

where:

$$
X_{i}^{(1)}(k)=X_{i}^{(0)}(k-1)+X_{i}^{(0)}(k)
$$

Then, the mean series is calculated:

$$
\mathrm{z}_{i}^{(1)}(k)=0.5 \mathrm{X}_{i}^{(1)}(k)+0.5 \mathrm{X}_{i}^{(1)}(k-1), k=2,3, \ldots, \mathrm{t}
$$

Using this series, the first-order differential equation based on a single variable is established and used as the prediction model (that is, the GM(1,1) model). The standard form of the gray difference equation is:

$$
\mathrm{X}_{i}^{(1)}(k)+a \mathrm{z}_{i}^{(1)}(k)=b
$$

where $\mathrm{a}$ and $\mathrm{b}$ are the development coefficient of the system and the grayscale of the endogenous control, respectively.

The estimation formula of the parameter vector $\hat{a}$ can be written in the following form:

$$
\begin{gathered}
\hat{a}=(a, b)^{T}=\left(B^{T} B\right)^{-1} B^{T} y \\
\text { where, } \mathrm{B}=\left[\begin{array}{cc}
-z_{i}^{(1)}(2) & 1 \\
-z_{i}^{(1)}(3) & 1 \\
\ldots & \ldots \\
-z_{i}^{(1)}(n) & 1
\end{array}\right] \text {, and } Y=\left[\begin{array}{c}
X_{i}^{(0)}(2) \\
X_{i}^{(0)}(3) \\
\ldots \\
X_{i}^{(0)}(n)
\end{array}\right]
\end{gathered}
$$

The time-response function of the $\mathrm{GM}(1,1)$ model is:

$$
\hat{x}_{i}^{(1)}(k)=\left(X_{i}^{(1)}(1)-\frac{b}{a}\right)^{e^{-a(k-1)}}+\frac{b}{a}
$$


Finally, the predicted values of the original series $\hat{x}_{i}^{(0)}(\mathrm{k})$ can be obtained by an inverse accumulated generating operation (IAGO):

$$
\hat{x}_{i}^{(0)}(\mathrm{k})=\hat{x}_{i}^{(1)}(k)-\hat{x}_{i}^{(1)}(k-1)=\left(\hat{x}_{i}^{(1)}(1)-\frac{b}{a}\right)\left(1-e^{a}\right) e^{-a(k-1)}
$$

\subsection{Prediction Accuracy Criterion}

Evaluating the accuracy of the model helps to determine the predictive effect of the selected model and provides a reference for forecasting results. Scientists have developed a variety of criterion for judging the accuracy of models $[125,126]$. Referring to these studies, in this paper, we selected two typical standards for this research. The first method of judgment is the trend map. By drawing the forecast curve and the actual curve, the trend graph can reflect the model's predictive effect. However, the trend map does not quantify the accuracy of predictions with specific numbers. The second judgement method uses the error measurement. MAPE and RMSE are commonly used tools for measuring prediction errors. Their specific formulas are as follows:

$$
\begin{gathered}
\text { RMSE }=\sqrt{\frac{1}{n} \sum_{i=1}^{n} e^{2}(i)} \\
\text { MAPE }=\frac{1}{n} \sum_{i=1}^{n}\left|\frac{e(i)}{x^{(0)}(i)}\right| \times 100 \%
\end{gathered}
$$

where $\mathrm{e}(i)=x^{(0)}(i)-\hat{x}^{(0)}(i)$ is the error, $x^{(0)}(i)$ is the actual value, and $\hat{x}^{(0)}(i)$ is the predicted value at the ith time point. According to the MAPE evaluation criteria in Table 5, the prediction accuracy can be divided into four levels.

Table 5. MAPE evaluation criterion.

\begin{tabular}{cccc}
\hline MAPE (\%) & Forecasting Ability & MAPE (\%) & Forecasting Ability \\
\hline$(-\infty, 10)$ & High & {$[20,50)$} & Reasonable \\
{$[10,20)$} & Good & $(50,+\infty)$ & Weak \\
\hline
\end{tabular}

\subsection{Experiment Environment and Data}

(1) Experiment environment

This thesis focuses on the forecasting of energy supply sustainability processing in the exponential smoothing and $\operatorname{GM}(1,1)$. The hardware resources environment of this experiment is Intel Core i5 $2.70 \mathrm{GHz}$, and the starting modeled memory gain of the $8 \mathrm{GiB}$ operating system environment is Ubuntu 18.04.1 LTS 64 bit. The programming language is Python3.6.5, and the third-party expansion package is NumPy pandas matplotlib stats models.

(2) Data sources

This research uses China as the sample and analyzes its energy supply sustainability. Primary data sources include: The National Bureau of Statistics of the People's Republic of China, China Statistics Yearbook (2000-2017), and the Wind Database of China [127]. The reserve and production ratios, the production diversity index, energy dependence, the total primary energy supply(TPES), total population number, energy price index, and clean power generation were taken from the National Bureau of Statistics of The People's Republic of China [128]. Imports of crude oil, gasoline, diesel oil, kerosene, natural gas and raw coal; distribution loss; power generation; market liquidity; and oil price, electricity distribution efficiency, and energy efficiency were taken from the Wind Database [127]. The waste water emissions, $\mathrm{SO}_{2}$ emissions, NOx emissions, forest coverage and domestic infrastructure were taken from the National Bureau of Statistics of the People's Republic of China [128]. 


\section{Empirical Findings}

Based on the research methods for energy supply sustainability in Section 3, we utilize the influencing factors of China's energy supply sustainability from 2000 to 2016 as the sample. First, China's energy supply sustainability index from 2000 to 2016 is calculated. Then, utilizing China's energy supply sustainability index from 2000 to 2010 as a training sample, and based on the forecasting methodology in Section 4, the optimum method for forecasting China's energy supply sustainability is screened. The findings show the validity of the method. The results are as follows.

\subsection{Comprehensive Evaluation Results}

Based on the evaluation indicators for the energy supply sustainability of China in Table 3, we adopt the entropy method in Section 3.3.2, calculate the weight of each indicator in Table 6, then, according to Equation (6), the ESSI from 2000 to 2016 is calculated, as shown in Figure 2. As shown in Table 6, the weight of each indicator is arranged in order: reserve and production ratio $>$ production diversity index $>$ clean power generation $>$ GDP per capita $>$ market liquidity $>$ sulfur dioxide emissions per capita $>$ land use $>$ NOx emissions per capita $>$ electricity distribution efficiency $>$ domestic infrastructure $>$ water pollution $>$ energy dependence $>$ TPEC per capita $>$ energy efficiency $>$ economic vulnerability index $>$ energy price index. Among these indicators, the reserve and production ratio, the production diversity index and the clean power generation indicators ranked in the top three. Analysis of the dimension level shows that energy availability had a maximum weight of 0.4321 , and energy technology and efficiency ranked second, with a weight of 0.2319; environment sustainability ranked third, with a weight of 0.2077 , and economic sustainability ranked fourth, with a weight of 0.1283 . These results fully demonstrated the importance of energy availability and technical sustainability to China's energy supply sustainability. These findings also show that environmental sustainability is an important guarantee for energy supply sustainability.

Table 6. Weights for each indicator of ESSI.

\begin{tabular}{|c|c|c|c|c|c|c|c|c|}
\hline Indicator & $\begin{array}{c}\text { Reserve and } \\
\text { Production } \\
\text { Ratio }\end{array}$ & $\begin{array}{c}\text { Production } \\
\text { Diversity Index }\end{array}$ & $\begin{array}{c}\text { Energy } \\
\text { Dependence }\end{array}$ & $\begin{array}{l}\text { TPEC Per } \\
\text { Capita }\end{array}$ & $\begin{array}{c}\text { Market } \\
\text { Liquidity }\end{array}$ & $\begin{array}{c}\text { Economic } \\
\text { Vulnerability } \\
\text { Index }\end{array}$ & $\begin{array}{l}\text { Energy Price } \\
\text { Index }\end{array}$ & $\begin{array}{l}\text { GDP Per } \\
\text { Capita }\end{array}$ \\
\hline Weight & 0.1648 & 0.1206 & 0.0412 & 0.04 & 0.0655 & 0.0326 & 0.0282 & 0.0675 \\
\hline Indicator & Water Pollution & $\begin{array}{l}\text { Sulfur Dioxide } \\
\text { Emissions Per } \\
\text { Capita }\end{array}$ & $\begin{array}{c}\text { NOx } \\
\text { Emissions } \\
\text { Per Capita }\end{array}$ & Land Use & $\begin{array}{c}\text { Clean } \\
\text { Power } \\
\text { Generation }\end{array}$ & $\begin{array}{l}\text { Domestic } \\
\text { Infrastructure }\end{array}$ & $\begin{array}{c}\text { Electricity } \\
\text { Distribution } \\
\text { Efficiency }\end{array}$ & $\begin{array}{c}\text { Energy } \\
\text { Efficiency }\end{array}$ \\
\hline Weight & 0.0422 & 0.0594 & 0.0505 & 0.0556 & 0.1003 & 0.0478 & 0.0496 & 0.0342 \\
\hline
\end{tabular}

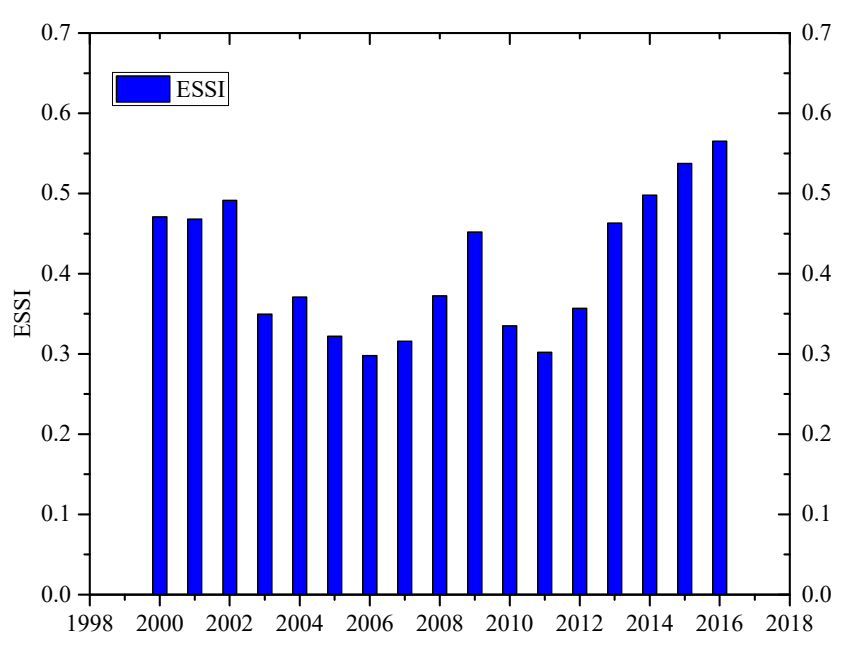

Figure 2. China's energy supply sustainability level from 2000 to 2016.

Figure 2 shows that China's energy supply sustainability has an asymmetric "W" trend from 2000 to 2016 and demonstrates an obvious phased characteristic. The energy supply sustainability level is low. The ESSI for China tends to increase from 2000 to 2002, and the sustainable level is 
between 0.45 to 0.5 , at level III. During this period, China's economic development was not high, and the GDP per capita was only approximately 0.8 million yuan. However, China had adequate energy reserves, low external dependence, strong availability and a low environmental pollution index. From 2003 to 2006, the ESSI significantly decreased to level IV, because China's economy developed rapidly during this period. The average annual GDP increased by $60 \%$ between 2000 and 2002. The energy dependence began to increase, and the pollutant emissions increased. Among these findings, the annual discharge of wastewater increased by $24 \%$, compared with the previous period. At the same time, China's energy efficiency did not improve significantly. From 2007 to 2009, the ESSI increased to level III, because China's annual investment in the fixed assets of the energy industry developed rapidly during this period. Annual investment in the fixed assets of the energy industry increased by $27 \%$, compared with 2003 to 2006. In 2009, energy consumption per GDP unit was $26 \%$ lower than in 2006. At the same time, people's livelihoods improved, and social security improved. By the end of 2009, per capita GDP was 55\% higher than in 2006. However, in 2009, the ESSI showed a significant improvement. The main reason may be the 2008 financial crisis, which caused the growth rate of China's major energy consumption products to decrease sharply, the energy demand to decline rapidly, and the energy supply to change from a tighter to a relatively short-term relative surplus. Energy prices decreased sharply in 2009, down 26\% from 2008. In 2010, the ESSI basically returned to the pre-2009 level, and it continued to improve after that year. The ESSI for China tended to increase from 2011 to 2016, with an average of 0.0589, and attained level II.

In recent years, China's energy supply sustainability level has increased significantly. This is due to the promotion of a series of national policies. China promulgated a new version of the "Emission Standards for Air Pollutants in Thermal Power Plants" (GB13223-2011) in 2011. The standard has significantly increased the emission concentration requirements for sulfur dioxide, nitrogen oxides and soot, and certain projects have been stricter than EU standards. The goal of the standard is to further promote thermal power plants to implement energy conservation and emissions reduction, reduce emissions, and increase waste treatment and disposal facilities to increase the treatment rate. In 2016, China put into operation 880 million kilowatts of flue gas desulfurization units in thermal power plants and 910 million kilowatts of flue gas denitrification units in thermal power plants, representing $83.8 \%$ and $86.7 \%$ of the capacity of thermal power units in China, respectively. Currently, the installation rate of denitrification and desulfurization units in China is at a relatively high level. Chinese Premier Li Keqiang made it clear that, to establish an energy and environmental security concept, it is necessary to move the environmental safety of energy to a strategic level and vigorously increase the proportion of green products and clean energy supply. China's clean energy development has made remarkable progress. In the first three quarters of 2017, wind power, photovoltaic power, and nuclear power generation represented $4.5 \%, 1.8 \%$, and $3.9 \%$ of the total power generation, respectively, showing an increasing trend year over year. Among these energy items, Guangdong's no fossil energy consumption represents approximately $43.5 \%$ of the total electricity consumption. These items will help to create a cleaner and low-carbon energy supply system and promote the sustainable development of the energy supply. However, China's macroeconomic reform has also restricted the formation of China's energy policy to a certain extent, explaining why the sustainability of China's energy supply has not been greatly improved [129].

\subsection{Optimality Analysis}

\subsubsection{Data Stationarity Test}

First, the ADF method is used to test the stationarity of energy supply sustainability and its indicators. The test results are shown in Table 7. ADF test statistics are calculated by dividing an estimate of $\mathrm{d}$ by its standard error. According to the ADF statistical standard (SS) by Fuller ([130], p. 373), although nearly all the data are unstable, most of the data become smooth after the first-order difference. In addition, all the data become smooth after the second-order difference. 
This finding shows that the sample data have the basic conditions of exponential smoothing prediction and $\mathrm{GM}(1,1)$ prediction.

Table 7. Stationary tests.

\begin{tabular}{ccccccc}
\hline \multirow{2}{*}{ Variable } & \multicolumn{2}{c}{ Level } & \multicolumn{2}{c}{ First Difference } & \multicolumn{2}{c}{ Second Difference } \\
\cline { 2 - 7 } & t-Statistic & Prob. & t-Statistic & Prob. & t-Statistic & Prob. \\
\hline x1 & $(-2.0484)^{* * *}$ & 0.2645 & $(-0.0789)^{* * *}$ & 0.2544 & $(-0.4085)^{* *}$ & 0.0291 \\
x2 & $(-0.8801)^{* * *}$ & 0.7672 & $(-4.1963)^{*}$ & 0.0064 & $(-7.5629)^{*}$ & 0 \\
x3 & $(-0.5226)^{* * *}$ & 0.859 & $(-0.0207)^{* * *}$ & 0.0017 & $(-8.0130)^{*}$ & 0 \\
x4 & $(-0.9265)^{* * *}$ & 0.7521 & $(-0.6660)^{* * *}$ & 0.1026 & $(-4.5970)^{*}$ & 0.0035 \\
x5 & $(-0.3198)^{* * *}$ & 0 & $(-0.6418)^{* * *}$ & 0.1068 & $(-5.1573)^{*}$ & 0.0024 \\
x6 & $(-1.4780)^{* * *}$ & 0.5184 & $(-4.3508)^{*}$ & 0.0048 & $(-6.4814)^{*}$ & 0.0002 \\
x7 & $(-3.0087)^{* *}$ & 0.0454 & $(-7.7424)^{*}$ & 0 & $(-4.4103)^{*}$ & 0.0063 \\
x8 & $(-3.1078)^{* *}$ & 1 & $(-0.1200)^{* * *}$ & 0.2401 & $(-4.9877)^{*}$ & 0.0021 \\
x9 & $(-3.0290)^{* * *}$ & 0.0548 & $(-6.4014)^{*}$ & 0.0001 & $(-5.6718)^{*}$ & 0.0012 \\
x10 & $(0.4878)^{* * *}$ & 0.9803 & $(-0.0435)^{* * *}$ & 0.0534 & $(-4.7978)^{*}$ & 0.0025 \\
x11 & $(0.2706)^{* * *}$ & 0.9683 & $(-4.0184)^{* *}$ & 0.0118 & $(-4.9198)^{*}$ & 0.0034 \\
x12 & $(-1.0350)^{* * *}$ & 0.7137 & $(-3.1679)^{* *}$ & 0.0428 & $(-5.1758)^{*}$ & 0.0019 \\
x13 & $(0.8848)^{* * *}$ & 0.9919 & $(-5.1850)^{* *}$ & 0.0011 & $(-8.1279)^{*}$ & 0 \\
x14 & $(-0.8970)^{* * *}$ & 0.7549 & $(-3.2774)^{* *}$ & 0.0403 & $(-1.7765)^{*}$ & 0.0327 \\
x15 & $(-6.3077)^{* * *}$ & 0.0002 & $(-0.2786)^{* * *}$ & 0.0002 & $(-6.3711)^{*}$ & 0.0003 \\
x16 & $(0.2627)^{* * *}$ & 0.9672 & $(-3.9333)^{* *}$ & 0.0105 & $(-4.8876)^{*}$ & 0.0021 \\
ESSI & $(-1.0813)^{* * *}$ & 0.6959 & $(-3.4268)^{* *}$ & 0.0268 & $(-3.5197)^{*}$ & 0.027 \\
\hline
\end{tabular}

${ }^{*}$-In the $1 \%$ significance level, ${ }^{* *}$ - In the $5 \%$ significance level, ${ }^{* * *}$-In the $10 \%$ significance level.

\subsubsection{Bayesian Information Criteria for Time Series}

The Bayesian information criteria is a method for determining the optimal model. Each variable obtains a different BIC value for each order of the MA, then obtains the optimal exponential smoothing model by calculating the BIC. For the same variable, smaller BIC values are better. Ledwina [131] proposed a data-driven smoothing test method based on BIC information selection criteria and used the BIC standard to select the dimension $\mathrm{k}$ of the smoothed density function. Kallenberg and Ledwina [132] used a Monte Carlo simulation to confirm that this method has suitable finite sample properties in practical applications. Inglot and Ledwina [133] theoretically proved that this method is progressively optimal regarding intermediate efficiency. Based on the historical data of the energy supply sustainability and its indicators from 2000 to 2016, the BIC values of energy supply sustainability and its indicators are shown in Table 8. Thus, the optimal smoothing times for each variable are obtained.

Table 8. BIC values of energy supply sustainability and its indicators.

\begin{tabular}{ccccc}
\hline \multirow{2}{*}{ Variable } & \multicolumn{3}{c}{ Smoothing Times } & \multirow{2}{*}{ Optimal Smoothing Times } \\
\cline { 2 - 4 } & $\mathbf{1}$ & $\mathbf{2}$ & $\mathbf{3}$ & \\
\hline x1 & 97.9123 & 96.8113 & 99.3577 & 2 \\
x2 & -46.8885 & $\mathrm{NaN}$ & $\mathrm{NaN}$ & 1 \\
x3 & -59.3967 & $\mathrm{NaN}$ & $\mathrm{NaN}$ & 1 \\
x4 & -9.2724 & -7.7188 & -5.9012 & 1 \\
x5 & 58.2847 & 57.3680 & 55.6523 & 3 \\
x6 & -92.0690 & $\mathrm{NaN}$ & $\mathrm{NaN}$ & 1 \\
x7 & 109.8997 & $\mathrm{NaN}$ & $\mathrm{NaN}$ & 1 \\
x8 & -15.9288 & $\mathrm{NaN}$ & $\mathrm{NaN}$ & 1 \\
x9 & 88.0625 & 88.3366 & 90.8277 & 1 \\
x10 & -147.43 & -145.267 & $\mathrm{NaN}$ & 1 \\
x11 & -171.003 & -168.389 & -166.609 & 1 \\
x12 & 38.0677 & 39.0169 & 36.4788 & 3 \\
x13 & -69.4097 & -67.2204 & -64.7617 & 1 \\
x14 & 232.4133 & $\mathrm{NaN}$ & $\mathrm{NaN}$ & 1 \\
x15 & -6.5838 & $\mathrm{NaN}$ & $\mathrm{NaN}$ & 1 \\
x16 & -30.8927 & -31.2931 & -29.8607 & 2 \\
ESSI & -23.6834 & -22.1323 & $\mathrm{NaN}$ & 1 \\
\hline
\end{tabular}

$\mathrm{NaN}-\mathrm{The}$ Bayesian information metric of the order is incalculable. 


\subsubsection{Experimental Results for the Accuracy of Different Models}

The ADF method shows that energy supply sustainability and its indicators have the basic conditions of exponential smoothing prediction and $\mathrm{GM}(1,1)$ prediction, and the optimal smoothing times of energy supply sustainability and its indicators are finally obtained from the Bayesian information criterion, using the ESSI as an example, to determine the best prediction model for China's energy supply sustainability. The specific process is as follows: using ESSI from 2000 to 2010 as the test data, the exponential smoothing and GM(1,1) models are used to predict ESSI from 2011 to 2016. Then, a grid search is used to traverse the weight combination, and the MAPE minimum is used as the standard to determine the optimal combination weight value. The final results of the grid search are as follows: the weight of the exponential smoothing model is 0.59 , and the weight of $\operatorname{GM}(1,1)$ is 0.41 . The optimal combination model is:

$$
\hat{x}_{i k}=0.59 \hat{x}_{i k}^{e s}+0.41 \hat{x}_{i k}^{g m}
$$

According to the combination model in Equation (31), we obtain the forecasting results of ESSI from 2011 to 2016, then compare these results with the forecasting results by the exponential smoothing single model, GM(1,1) single model, and the actual value of ESSI from 2011 to 2016. The forecasting trend map is shown in Figure 3. Figure 3 clearly shows that the prediction result of the exponential smoothing single model is higher than the original value, and the prediction result of the $\operatorname{GM}(1,1)$ single model is lower than the original value. The predicted results of ESSI by the exponential smoothing single model are more accurate than those of the $\mathrm{GM}(1,1)$ single model. However, overall, the exponential smoothing-GM(1,1) hybrid model is the most accurate for the prediction of ESSI. From the MAPE in Table 9, the MAPE of the exponential smoothing single model and the GM(1,1) single model are both less than $20 \%$, which achieves a better prediction accuracy. The hybrid model is more accurate, and the MAPE is only $2 \%$. The results of RMSE also show that the combined model has a high reliability, again proving the validity and reliability of the model selected in this paper.

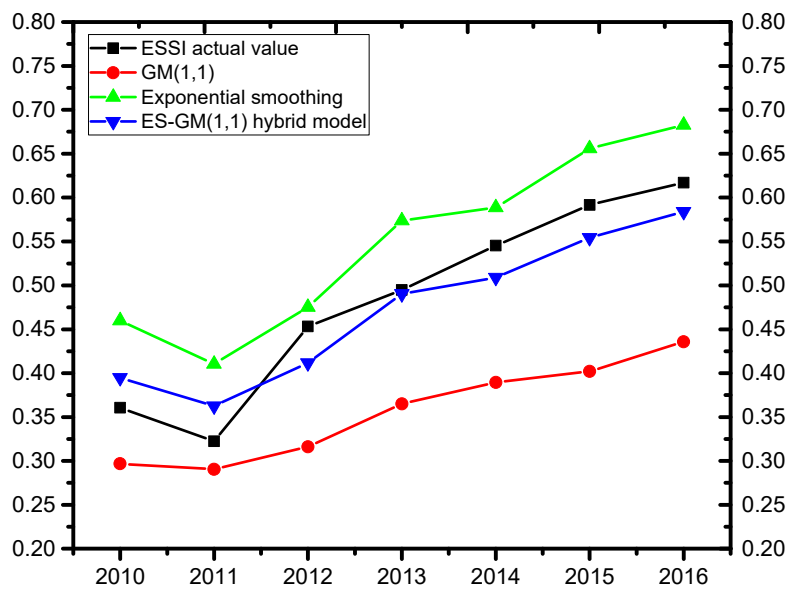

Figure 3. Comparison of the test results of single and combined models.

Table 9. The RMSE and MAPE values for the three models.

\begin{tabular}{cccc}
\hline Error & GM(1,1) & Exponential Smoothing & ES-GM(1,1) Hybrid Model \\
\hline RMSE & 0.1123 & 0.0760 & 0.0278 \\
MAPE & 0.1920 & 0.1860 & 0.0201 \\
\hline
\end{tabular}




\subsection{Forecasting Results}

\subsubsection{Forecasting Results and Analysis of Each Dimension of ESSI}

Using the historical data of each indicator of China's energy supply sustainability from 2000 to 2016 as a sample, adopting the optimal exponential smoothing-GM(1,1) hybrid model, we obtain the forecasting results of each indicator of China's energy supply sustainability, then analyze these results in depth, as shown in Figures 4-7.

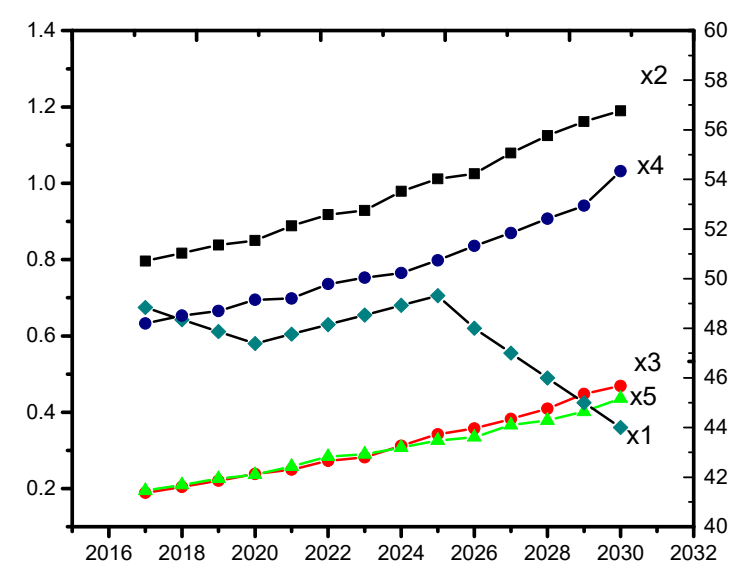

Figure 4. Predictions for the energy availability of ESSI.

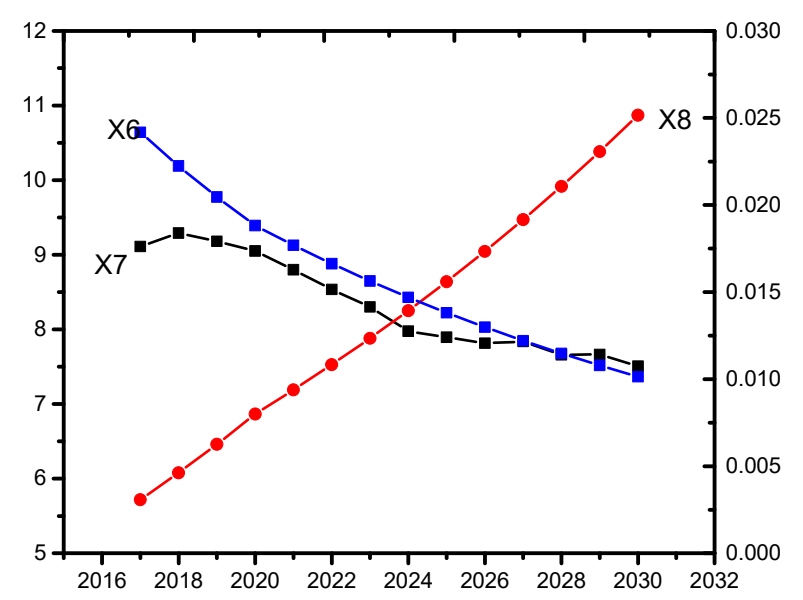

Figure 5. Predictions for the economic sustainability of ESSI.

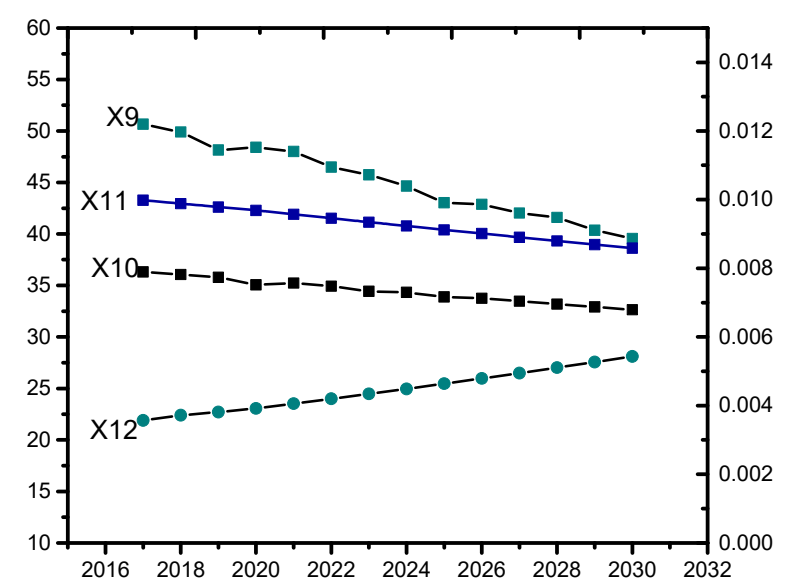

Figure 6. Predictions for the environmental sustainability of ESSI. 


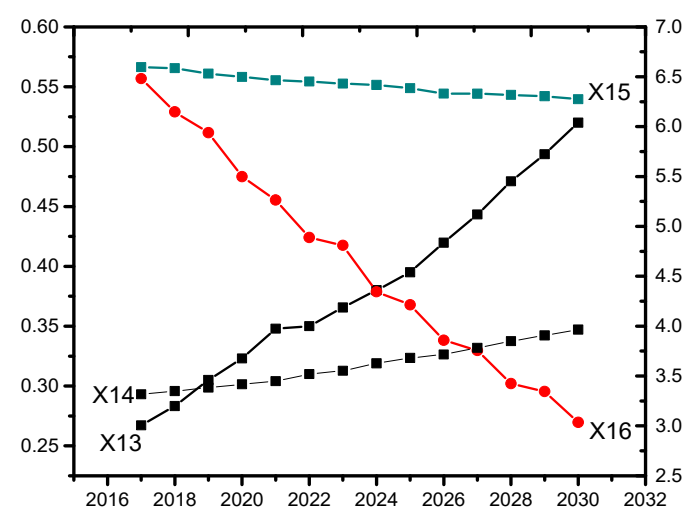

Figure 7. Predictions for the technical sustainability of ESSI.

The energy supply availability forecasting results in Figure 4 indicate that, except for a minor reduction in the reserve and production ratio, the remaining four indicators in this dimension are on the rise. In the short term, the reduction in energy reserve and production will be small, and in the long run, China's energy supply will remain relatively stable. By 2030, the reserve and production ratio will be 44 . In recent years, the Chinese government has implemented a variety of measures to stabilize the energy supply and maintain the oil reserve and production ratio at approximately 13.8. Moreover, China has achieved breakthroughs in coal-to-methanol, methanol-to-olefin and coal-to-oil technologies and has mastered strategic alternative technologies in both transportation fuels and chemical products. For example, in mining, the Bulianta Coal Mine of the Shenhua group of China has, since 2017, adopted a working face that is $8 \mathrm{~m}$ high. One working face can recover 1.2 million tons of coal within 48 months, and the recovery rate is as high as $98 \%$. The energy production diversity will continue to increase, because the Chinese government attaches great importance to the development of no fossil energy. According to data released by the International Energy Agency (IEA), in 2017 alone, China spent $\$ 132$ billion on clean energy systems, which is more than that spent by the US and EU combined. China's onshore wind power represented approximately $35 \%$ of the world's total in 2017, and the average utilization hours of wind power in China were $1948 \mathrm{~h}$, which is an increase of $203 \mathrm{~h}$. However, compared with the developed countries in the world, China's share of renewable energy is still relatively low, and the energy production diversity of $75 \%$ of EU countries is higher than this level [134]. China's energy dependence will also continue to increase, because China is undergoing an energy transformation, and the demand for oil and natural gas has greatly increased. In 2017, China's dependence on foreign oil grew to $72.3 \%$. However, with the promotion of the Belt and Road Initiative, China Petroleum has cooperated with other countries and has achieved more international cooperation. Hence, the market liquidity of oil will continue to improve.

The economic sustainability forecasting results in Figure 5 indicate that the economic vulnerability index and the energy price index will show a downward trend for a long time, and GDP per capita will rise in both the short and the long term. First, China's economic vulnerability index will continue to decrease, because China's ability to withstand rising oil prices and large fluctuations will gradually increase as China's energy diversification level increases and a series of strategies to delay oil consumption growth are implemented. Second, China's energy product price index fluctuates unsteadily and rises in the short term. However, overall, it is lower than the historical energy price index, mainly because China's energy price reform process is slow [135]. In 2015, China's "Several Opinions of the Central Committee of the Communist Party of China and the State Council on Promoting the Reform of the Price Mechanism" noted that, by 2017, China's competitive areas and links were basically liberalized, and by 2020 , the market-determined price mechanism will be basically improved. With the implementation of a series of policies, China's energy prices will be reduced in the long run. GDP per capita will grow at a rate of $6.63 \%$ in the short term, from 2017 to 2020, which is close to the predictions of $6.67 \%$ by Pao (2012) [44] and $6.5 \%$ by Yuan [136]. Since 2008, China's total GDP has 
surpassed that of Japan, becoming the world's second largest economy. However, from the perspective of per capita GDP, China remains far behind developed countries. In the long run, China's GDP per capita growth will decrease by approximately $4.7 \%$ in 2030.

The environmental sustainability forecasting results in Figure 6 show that, from 2017 to 2030, China's per capita wastewater discharge, per capita sulfur dioxide emissions, and per capita NOx emissions all showed a downward trend, and the forest coverage will rise. Specifically, in the short term, from 2017 to 2021 , the average deceleration rates of the three are $1.5 \%, 1 \%$, and $1 \%$, respectively. In the long run, by 2030 , the rate of decline will increase to $2 \%, 1.5 \%$ and $1.5 \%$, respectively. The main reason is the implementation of the "Water Pollution Prevention Action Plan" (Water 10 Articles 2015), "Fire Power Plant Air Pollutant Emission Standards" (2011), "Atmosphere Ten Articles" (2015) and other policies introduced by the Chinese government in recent years. Using Beijing as an example, in 2017, Beijing's "good days" were 226 days, an increase of 28 days, compared with 2016. It had 23 "heavy pollution days", which was 16 days fewer than in 2016. In 2017, the concentration of sulfur dioxide in Beijing was "single digit", which is much better than the national standard $\left(60 \mu \mathrm{g} / \mathrm{m}^{3}\right)$. Forests are not only related to national ecological security but are also the main content of China's sustainable development in the new era. On October 18, 2017, Chinese president, $X_{i}$ Jinping, in the report of the 19th National Congress, noted that, to adhere to the harmonious coexistence of man and nature, it is necessary to establish and practice the concept of green water and green hills, which is the concept of Jinshan and Yinshan. The president also noted that it is important to adhere to the basic national policy of conserving resources and protecting the environment. According to the forecast of this paper, China's forest coverage rate is expected to maintain a growth rate of $1.6 \%$ in 2017-2020, achieving $23.06 \%$ in 2020. After 2020, the growth rate will increase to $2 \%$. By 2030, forest coverage will exceed $28 \%$, and China's rate will match the world's average level.

The technical sustainability forecasting results in Figure 7 show that, in 2017-2030, China's clean power generation ratio and investment in fixed assets of energy industry will increase, and electricity distribution efficiency and energy consumption per unit GDP will decline. In the short term, from 2017 to 2021, the clean power generation ratio and investment in the fixed assets of the energy industry will increase by $1.86 \%$ and $1 \%$, respectively. In addition, by 2030 , the growth rate will rise to $2 \%$ and $1.5 \%$, respectively. In the short term, from 2017 to 2021, electricity distribution efficiency and energy consumption per unit GDP will decrease by $0.5 \%$ and $5 \%$, respectively. In the long term, electricity distribution efficiency will increase to $0.4 \%$ by 2030 , and the rate of energy consumption per unit GDP will decrease by $5.5 \%$. In sum, the proportion of clean energy generation is increasing faster than the fixed asset investment of the energy industry, and the energy consumption per unit GDP is decreasing faster than the loss rate of distribution. By 2030, the proportion of non-fossil energy in China will grow to approximately $20 \%$, and the energy consumption per unit GDP will be reduced to $0.27 \%$. This is because, given an increasingly serious energy crisis, energy development or energy efficiency enhancement has become a key component of energy security strategies. China has proffered clear requirements for improving energy efficiency in the China Energy 13th Five-Year Plan and the China Energy Security Development Strategy.

\subsubsection{Prediction Results and Analysis of ESSI}

The exponential smoothing-GM(1,1) hybrid prediction model was selected in Section 5.2, using the predicted values of each indicator for the energy supply sustainability, measured in Section 5.3.1. It also refers to the two different forecasting approaches for energy supply sustainability in Section 4.1. We calculated the forecast energy supply sustainability index, ESSI $I_{1}^{*}$, by weighting the forecast index value of each indicator, and we determined the forecast energy supply sustainability index, ESSI $I_{2}^{*}$, directly from ESSI, as shown in Figure 8. In this paper, China's energy supply sustainability is not only predicted for the short term, from 2017 to 2020, but also for the long term, from 2020 to 2030. 


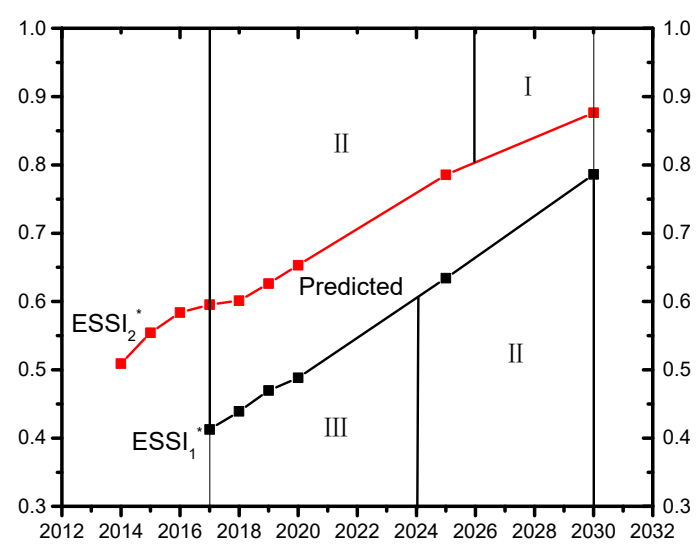

Figure 8. Forecasting results for China's energy supply sustainability.

Figure 8 clearly shows that the forecasting results for China's energy supply sustainability from 2017 to 2020 by scheme 1 is far from its actual value in 2016. From this result, it can be judged that scheme 2 is more accurate in predicting the sustainability of China's energy supply. Therefore, using the forecast result $E S S I_{2}^{*}$ of scheme 2 as a reference, this paper conducts a detailed analysis of the development trend of the sustainable level of energy supply in China in the short and long term. In the short term, the sustainable level of the energy supply in China will increase steadily from 2017 to 2020 , with an average annual increase of $3.23 \%$, but at level II in the short term. This is because China's energy supply sustainability starting point is low, and many unsustainable factors remain. In particular, China's resource endowment characteristics make it difficult for it to change its coal-based energy structure in the short term. Coal will represent approximately $60 \%$ of China's total energy supply by 2020, which will lead to a low diversification of the energy supply, a high degree of external dependence and a high degree of environmental pollution in China.

The Chinese government has implemented many measures to support the development of renewable energy, although in the short term, there are problems relating to inadequate absorption and a lag in technology. Compared with other developed countries, China has a lower proportion of renewable energy. Moreover, China's scientific and technological progress has a low starting point and a strong lag. Most of China's energy is heavily dependent on imports [137], which will seriously affect the sustainable level of China's energy supply in the short term. Denmark is the country with the safest and most sustainable energy in the Organization for Economic Cooperation and Development. Denmark has reduced its dependence on foreign energy sources to zero and achieved full self-sufficiency. The country's commitment to energy efficiency, long-term taxes on energy fuels, electricity and carbon dioxide, and incentives for cogeneration (CHP) and wind turbines are all worth learning from [138]. The Chinese government will also further implement a series of policy measures to improve China's energy supply structure and improve its sustainability level. China's "Revolutionary Strategy for Energy production and consumption (2016-2030)" clearly notes that, by 2030, the proportion of natural gas and no fossil energy in China's energy consumption will increase to $35 \%$. By then, the proportion of coal supply will decrease to approximately $42 \%$, which is close to Britain's level in 2014. Therefore, beginning in 2026, China's energy supply sustainability will be greatly improved. $E S S I_{2}^{*}$ will be higher than 0.8 , and the level of sustainability of China's energy supply will be upgraded to the safe level (level I). By 2030, ESSI $I_{2}^{*}$ will be increased to 0.8765 .

\section{Conclusions}

Energy supply is the core issue relating to energy security. The sustainability of energy supplies is an important issue in the field of energy security, especially given increasing global warming and various environmental problems caused by fossil fuel combustion. The sustainability of energy supplies has become a common global demand of humans. The sustainability of the energy supply is more significant than that of the actual energy supply, as it focuses more on the equity of energy 
supply and environmental sustainability. Some scholars have noted the environmental aspects of energy security, and some organizations have raised the issue of sustainable energy development. However, the sustainability of energy supplies has not been studied in depth. In-depth research on the sustainability of energy supplies is in accordance with the social requirements and the law of scientific development. It is of great significance to further deepen research in the field of energy security and to promote the sustainable development of energy supplies in countries or regions. On the basis of the research on energy security and sustainability by the relevant organizations and scholars, this paper creatively proffers a definition of energy supply sustainability, defines it and proffers the corresponding impact indicator system. Furthermore, the measurement method of the sustainability level of the energy supply, based on the entropy method, and the combined forecasting method of the energy supply sustainability level, based on exponential smoothing-GM(1,1), are proposed. Finally, using China as an example, this paper evaluates and predicts the sustainable level of the energy supply in China by using the above methods, which proves the validity of this method.

First, the comprehensive evaluation results show that the reserve and production ratio, the production diversity and the clean energy power generation ratio rank as the top three factors for energy supply sustainability. This conclusion is in accordance with international standards for sustainable energy development. By comparing previous studies, it is found that countries with a stable energy supply, a high degree of diversification, a low degree of external dependence and a suitable development of clean energy, such as the Netherlands and Germany [19], have a lower energy risk. From the perspective of dimensions, energy reliability, energy efficiency and environmental sustainability rank in the top three, and economic sustainability ranks fourth. This conclusion is in accordance with China's reality and fully reflects that energy reliability is the basic guarantee of energy supply sustainability. Energy efficiency and environmental sustainability are key issues for a sustainable energy supply in China. The equity of the energy supply in China is relatively strong; therefore, the weight of this dimension is the lowest.

Comparing experiments on exponential smoothing, the GM(1,1) single model and the exponential smoothing-GM $(1,1)$ hybrid model, it is ultimately found that the exponential smoothing-GM $(1,1)$ hybrid model has the lowest RMSE and MAPE for predicting the sustainable level of the energy supply in China. The results are only $2 \%$ of the MAPE and 0.0278 of the RMSE, with the highest accuracy. The experimental results showed that the exponential smoothing-GM(1,1) hybrid model was not only suitable for the prediction of the energy supply sustainability in the future but also suitable for the prediction of various impact indicators relating to energy supply sustainability in the future.

The forecasting results show that, in the short term, from 2017 to 2020, China's coal-based energy structure will be difficult to change, and the proportion of renewable energy is low. Therefore, many unsustainable factors remain in China's energy supply system. The level of sustainability is low, at level II. In the long run, with the diversification of China's energy supply and the energy technology progress, the sustainable level of China's energy supply will be greatly improved. By 2030, the sustainable level of China's energy supply will be raised to 0.8765 , attaining level I. However, compared with Sweden and other countries with high levels of energy security and strong sustainability, China continues to have a large gap, because China has outdated low-carbon emissions and energy efficiency policies. There is no universal solution to all countries' energy problems. We should further integrate China's energy characteristics and social development process to formulate real-time sustainable solutions for the promotion of a sustainable energy supply and sustainable social development.

Author Contributions: All authors contributed equally to this work. J.Z. proposed the original idea and modified and refined the manuscript. P.L. designed this research and wrote this paper. All authors read and approved the final manuscript.

Funding: This research received no external funding.

Acknowledgments: This research was supported by the National Natural Science Foundation of China (NSFC), under Grant (no. 71273206, 71704140), the National Soft Science Plan Program(no. 2013GXS4D151) and the Soft 
Science Research Major Program of Shaanxi Province(no. 2012KR2-01), Shaanxi Province education department science and technology research plan(17JZ049). The authors sincerely thank the anonymous referees as well as the editors.

Conflicts of Interest: The authors declare no conflict of interest.

\section{References}

1. Pachauri, R.K.; Allen, M.R.; Barros, V.R. Climate change 2014: Synthesis report. In Contribution of Working Groups I, II and III to the Fifth Assessment Report of the Intergovernmental Panel on Climate Change; IPCC: Paris, France, 2014.

2. Mousavi, B.; Lopez, N.S.A.; Biona, J.B.M. Driving forces of Iran's $\mathrm{CO}_{2}$ emissions from energy consumption: An LMDI decomposition approach. Appl. Energy 2017, 206, 804-814. [CrossRef]

3. Ali, S.H.; Giurco, D.; Arndt, N. Mineral supply for sustainable development requires resource governance. Nature 2017, 543, 367-372. [CrossRef] [PubMed]

4. Chu, S.; Majumdar, A. Opportunities and challenges for a sustainable energy future. Nature 2012, 488, $294-303$. [CrossRef] [PubMed]

5. Res, A. Resolution Adopted by the General Assembly on 6 July 2017. Un Gen. Assem. 2017, 71, 313.

6. Nerini, F.F.; Tomei, J.; To, L.S.; Bisaga, I.; Parikh, P.; Black, M.; Borrion, A.; Spataru, C.; Broto, V.C.; Anandarajah, G.; et al. Mapping synergies and trade-offs between energy and the Sustainable Development Goals. Nat. Energy 2018, 3, 10. [CrossRef]

7. Holley, C.; Lecavalier, E. Energy governance, energy security and environmental sustainability: A case study from Hong Kong. Energy Policy 2017, 108, 379-389. [CrossRef]

8. British Petroleum. BP Statistical Review of World Energy; British Petroleum: London, UK, 2018.

9. Ren, J.; Sovacool, B.K. Enhancing China's energy security: Determining influential factors and effective strategic measures. Energy Convers. Manang. 2014, 88, 589-597. [CrossRef]

10. Demski, C.; Poortinga, W.; Whitmarsh, L. National context is a key determinant of energy security concerns across Europe. Nat. Energy 2018, 3, 882-888. [CrossRef]

11. Matsumoto, K.; Doumpos, M.; Andriosopoulos, K. Historical energy security performance in EU countries. Renew. Sustain. Energy Rev. 2018, 82, 1737-1748. [CrossRef]

12. IEA. Towards a Sustainable Energy Future; OECD/IEA: Paris, France, 2001.

13. IEA. World Energy Outlook; OECD/IEA: Paris, France, 2007.

14. APERC. Quest for Energy Security in the 21st Century: Resources and Constraints; Asia Pacific Energy Research Centre: Tokyo, Japan, 2007.

15. LeCoq, C.; Paltseva, E. Measuring the security of external energy supply in the European Union. Energy Policy 2009, 37, 4474-4481. [CrossRef]

16. Sovacool, B.K.; Mukherjee, I.; Drupady, I.M. Evaluating energy security performance from 1990 to 2010 for eighteen countries. Energy 2011, 36, 5846-5853. [CrossRef]

17. Ren, J.; Sovacool, B.K. Prioritizing low-carbon energy sources to enhance China's energy security. Energy Convers. Manang. 2015, 92, 129-136. [CrossRef]

18. Sovacool, B.K.; Mukherjee, I. Conceptualizing and measuring energy security: A synthesized approach. Energy 2011, 36, 5343-5355. [CrossRef]

19. Radovanović, M.; Filipović, S.; Pavlović, D. Energy security measurement-A sustainable approach. Renew. Sustain. Energy Rev. 2017, 68, 1020-1032. [CrossRef]

20. Ang, B.W.; Choong, W.L.; Ng, T.S. Energy security: Definitions, dimensions and indexes. Renew. Sustain. Energy Rev. 2015, 42, 1077-1093. [CrossRef]

21. Zhang, L.; Yu, J.; Sovacool, B.K. Measuring energy security performance within China: Toward an inter-provincial prospective. Energy 2017, 125, 825-836. [CrossRef]

22. Brown, M.A.; Sovacool, B.K. Developing an 'energy sustainability index' to evaluate energy policy. Interdiscip. Sci. Rev. 2007, 32, 335-349. [CrossRef]

23. Afgan, N.H.; Carvalho, M.G. Sustainability assessment of a hybrid energy system. Energy Policy 2008, 36, $2903-2910$. [CrossRef]

24. Tsai, W. Energy sustainability from analysis of sustainable development indicators: A case study in Taiwan. Renew. Sustain. Energy Rev. 2010, 14, 2131-2138. [CrossRef] 
25. Kumar, D.; Katoch, S.S. Sustainability indicators for run of the river (RoR) hydropower projects in hydro rich regions of India. Renew. Sustain. Energy Rev. 2014, 35, 101-108. [CrossRef]

26. Mainali, B.; Silveira, S. Using a sustainability index to assess energy technologies for rural electrification. Renew. Sustain. Energy Rev. 2015, 41, 1351-1365. [CrossRef]

27. Iddrisu, I.; Bhattacharyya, S.C. Sustainable Energy Development Index: A multi-dimensional indicator for measuring sustainable energy development. Renew. Sustain. Energy Rev. 2015, 50, 513-530. [CrossRef]

28. Ibrahim, M.S. Analysis and evalution of five short-term load forecasting techniques. IEEE Trans. Power Syst. 1989, 4, 1484-1491.

29. Liu, C.; Hu, Z.; Li, Y. Forecasting copper prices by decision tree learning. Resour. Policy 2017, 52, 427-434. [CrossRef]

30. Ediger, V.; Akar, S. ARIMA forecasting of primary energy demand by fuel in Turkey. Energy Policy 2007, 35, $1701-1708$. [CrossRef]

31. Pappas, S.S.; Ekonomou, L.; Karamousantas, D.C.; Chatzarakis, G.E.; Katsikas, S.K.; Liatsis, P. Electricity demand loads modeling using AutoRegressive Moving Average (ARMA) models. Energy 2008, 9, 1353-1360. [CrossRef]

32. Voudouris, V.; Stasinopoulos, D.; Rigby, R. The ACEGES laboratory for energy policy: Exploring the production of crude oil. Energy Policy 2011, 39, 5480-5489. [CrossRef]

33. Voudouris, V.; Matsumoto, K.; Sedgwick, J. Exploring the production of natural gas through the lenses of the ACEGES model. Energy Policy 2014, 64, 124-133. [CrossRef]

34. Matsumoto, K. Evaluation of an artificial market approach for GHG emissions trading analysis. Simul. Model. Pract. Theory 2008, 16, 1312-1322. [CrossRef]

35. Wang, Q.; Li, S.; Li, R. Forecasting energy demand in China and India: Using single-linear, hybrid-linear, and non-linear time series forecast techniques. Energy 2018, 7, 168. [CrossRef]

36. Esen, H.; Ozgen, F.; Esen, M.; Sengur, A. Modelling of a new solar air heater through least-squares support vector machines. Expert Syst. Appl. 2009, 7, 10673-10682. [CrossRef]

37. Ghosh, R.; Purkayastha, P. Forecasting Profitability in Equity Trades Using Random Forest, Support Vector Machine and Xgboost. In Proceedings of the 10th International Conference on Recent Trends in Engineering Science and Management, Chennai, India, 14-15 July 2017; pp. 473-486.

38. Li, P.; Zhang, J. A New Hybrid Method for China's Energy Supply Security Forecasting Based on ARIMA and XGBoost. Energies 2018, 11, 1687. [CrossRef]

39. Afionis, S.; Stringer, L.C. European Union leadership in biofuels regulation: Europe as a normative power. J. Clean. Prod. 2012, 3, 114-123. [CrossRef]

40. Xu, W.; Gu, R.; Liu, Y. Forecasting energy consumption using a new GM-ARMA model based on HP filter: The case of Guangdong province of China. Econ. Model. 2015, 45, 127-135. [CrossRef]

41. Oliveira, E.M.; Oliveira, F.L.C. Forecasting mid-long term electric energy consumption through bagging ARIMA and exponential smoothing methods. Energy 2018, 144, 776-788. [CrossRef]

42. Dong, Z.; Yang, D.; Reindl, T. Short-term solar irradiance forecasting using exponential smoothing state space model. Energy 2013, 55, 1104-1113. [CrossRef]

43. Cadenas, E.; Jaramillo, O.A.; Rivera, W. Analysis and forecasting of wind velocity in Chetumal, quintanaroo, using the single exponential smoothing method. Renew. Energy 2010, 35, 925-930. [CrossRef]

44. Pao, $\mathrm{H}$.; Fu, H.; Tseng, C. Forecasting of $\mathrm{CO}_{2}$ emissions, energy consumption and economic growth in China using an improved grey model. Energy 2012, 40, 400-409. [CrossRef]

45. Wang, J.; Yan, R.; Hollister, K. A historic review of management science research in China. Omega 2008, 6, 919-932. [CrossRef]

46. Sun, W.; Liu, M. Prediction and analysis of the three major industries and residential consumption $\mathrm{CO}_{2}$ emissions based on least squares support vector machine in China. J. Clean. Prod. 2016, 122, 144-153. [CrossRef]

47. Wang, Z.; Li, Q.; Pei, L. A seasonal GM(1,1) model for forecasting the electricity consumption of the primary economic sectors. Energy 2018, 154, 522-534. [CrossRef]

48. Yuan, C.; Liu, S.; Fang, Z. Comparison of China's primary energy consumption forecasting by using ARIMA (the autoregressive integrated moving average) model and GM(1,1) model. Energy 2016, 100, 384-390. [CrossRef] 
49. Su, M.; Zhang, M.; Lu, W. ENA-based evaluation of energy supply security: Comparison between the Chinese crude oil and natural gas supply systems. Renew. Sustain. Energy Rev. 2017, 72, 888-899. [CrossRef]

50. Chester, L. Conceptualising energy security and making explicit its polysemic nature. Energy Policy 2010, 38, 887-895. [CrossRef]

51. Carrera, D.G.; Mack, A. Sustainability assessment of energy technologies via social indicators: Results of a survey among European energy experts. Energy Policy 2010, 38, 1030-1039. [CrossRef]

52. Begić, F.; Afgan, N.H. Sustainability assessment tool for the decision making in selection of energy system-Bosnian case. Energy 2007, 32, 1979-1985. [CrossRef]

53. Santoyo-Castelazo, E.; Azapagic, A. Sustainability assessment of energy systems: Integrating environmental, economic and social aspects. J. Clean. Prod. 2014, 80, 119-138. [CrossRef]

54. Krey, V.; Riahi, K.; Mccollum, D.L. An integrated approach to energy sustainability. Nat. Clim. Chang. 2011, 9, 1227.

55. Verani, S.; Sperandio, G.; Picchio, R. Sustainability assessment of a self-consumption wood-energy chain on small scale for heat generation in central Italy. Energies 2015, 8, 5182-5197. [CrossRef]

56. Mondal, M.A.H.; Denich, M. Assessment of renewable energy resources potential for electricity generation in Bangladesh. Renew. Sustain. Energy Rev. 2010, 14, 2401-2413. [CrossRef]

57. Duan, F.; Ji, Q.; Liu, B. Energy investment risk assessment for nations along China's Belt \& Road Initiative. J. Clean. Prod. 2018, 170, 535-547.

58. Narula, K.; Reddy, B.S. A SES (sustainable energy security) index for developing countries. Energy 2016, 94, $326-343$. [CrossRef]

59. Sovacool, B.K.; Walter, G. Major hydropower states, sustainable development, and energy security: Insights from a preliminary cross-comparative assessment. Energy 2018, 142, 1074-1082. [CrossRef]

60. Bacher, P.; Madsen, H.; Nielsen, H.A. Online short-term solar power forecasting. Sol. Energy 2009, 83, $1772-1783$. [CrossRef]

61. Mellit, A.; Pavan, A.M. A 24-h forecast of solar irradiance using artificial neural network: Application for performance prediction of a grid-connected PV plant at Trieste, Italy. Sol. Energy 2010, 84, 807-821. [CrossRef]

62. Pinson, P.; Nielsen, H.A.; Møller, J.K. Non-parametric probabilistic forecasts of wind power: Required properties and evaluation. Wind Energy 2007, 10, 497-516. [CrossRef]

63. Pedro, H.T.C.; Coimbra, C.F.M. Assessment of forecasting techniques for solar power production with no exogenous inputs. Sol. Energy 2012, 86, 2017-2028. [CrossRef]

64. Lorenz, E.; Hurka, J.; Heinemann, D. Irradiance Forecasting for the Power Prediction of Grid-Connected Photovoltaic Systems. IEEE Jstars 2009, 2, 2-10. [CrossRef]

65. Bludszuweit, H.; Dominguez-Navarro, J.A.; Llombart, A. Statistical analysis of wind power forecast error. IEEE Trans. Power Syst. 2008, 23, 983-991. [CrossRef]

66. Ekonomou, L. Greek long-term energy consumption prediction using artificial neural networks. Energy 2010, 35, 512-517. [CrossRef]

67. Tan, Z.; Zhang, J.; Xu, J. Day-ahead electricity price forecasting using wavelet transform combined with ARIMA and GARCH models. Appl. Energy 2010, 11, 3606-3610. [CrossRef]

68. Wang, Y.; Liu, L.; Wu, C. Forecasting the real prices of crude oil using forecast combinations over time-varying parameter models. Energy Econ. 2017, 66, 337-348. [CrossRef]

69. Du, P.; Wang, J.; Yang, W. Multi-step ahead forecasting in electrical power system using a hybrid forecasting system. Renew. Energy 2018, 122, 533-550. [CrossRef]

70. Ziel, F.; Steinert, R.; Husmann, S. Efficient modeling and forecasting of electricity spot prices. Energy Econ. 2015, 47, 98-111. [CrossRef]

71. Matsumoto, K.; Voudouris, V. Potential impact of unconventional oil resources on major oil-producing countries: Scenario analysis with the ACEGES model. Nat. Resour. Res. 2015, 24, 107-119. [CrossRef]

72. Prema, V.; Rao, K.U. Development of statistical time series models for solar power prediction. Renew. Energy 2015, 83, 100-109. [CrossRef]

73. Trapero, J.R.; Kourentzes, N.; Martin, A. Short-term solar irradiation forecasting based on Dynamic Harmonic Regression. Energy 2015, 84, 289-295. [CrossRef]

74. Meng, M.; Niu, D.; Shang, W. A small-sample hybrid model for forecasting energy-related $\mathrm{CO}_{2}$ emissions. Energy 2014, 64, 673-677. [CrossRef]

75. Xiong, P.; Dang, Y.; Yao, T. Optimal modeling and forecasting of the energy consumption and production in China. Energy 2014, 77, 623-634. [CrossRef] 
76. Sovacool, B.K. National context drives concerns. Nat. Energy 2018, 3, 820-821. [CrossRef]

77. Ang, B.W.; Choong, W.L.; Ng, T.S. A framework for evaluating Singapore's energy security. Appl. Energy 2015, 148, 314-325. [CrossRef]

78. Narula, K.; Reddy, B.S. Three blind men and an elephant: The case of energy indices to measure energy security and energy sustainability. Energy 2015, 80, 148-158. [CrossRef]

79. Ecn, M. EU Standards for Energy Security of Supply. Gas 2007, 6, 5-31.

80. Merino-Saum, A.; Baldi, M.G.; Gunderson, I. Articulating natural resources and sustainable development goals through green economy indicators: A systematic analysis. Energy Convers. Manang. 2018, 139, 90-103. [CrossRef]

81. Modi, V.; McDade, S.; Lallement, D. Energy services for the millennium development goals. In Energy Services for the Millennium Development Goals; UN Millennium Project, and World Bank: Washington, DC, USA, 2006.

82. Shortall, R.; Davidsdottir, B.; Axelsson, G. Geothermal energy for sustainable development: A review of sustainability impacts and assessment frameworks. Renew. Sustain. Energy Rev. 2015, 44, 391-406. [CrossRef]

83. Wyman, O. Energy Sustainability Index: World Energy Council. In Das Master-Studium: Erweitern und vertiefen Sie Ihre Kenntnisse; World Energy Council: London, UK, 2013.

84. Sovacool, B.K.; Saunders, H. Competing policy packages and the complexity of energy security. Energy 2014, 67, 641-651. [CrossRef]

85. Von, H.D. Energy Security (East Asia). In Berkshire Encyclopedia of Sustainability: China, India, and East and Southeast Asia: Assessing Sustainability; Berkshire Publishing Group: Great Barrington, MA, USA, 2012; pp. 143-150.

86. Drexel, K. The U.S. Department of Defense: Valuing energy security. J. Eenrgy Eng.-Asce 2009, 7.

87. Bringezu, S.; Potočnik, J.; Schandl, H. Multi-Scale governance of sustainable natural resource use-challenges and opportunities for monitoring and institutional development at the national and global level. Sustainability 2016, 8, 778. [CrossRef]

88. Laldjebaev, M.; Morreale, S.J.; Sovacool, B.K. Rethinking energy security and services in practice: National vulnerability and three energy pathways in Tajikistan. Energy Policy 2018, 114, 39-50. [CrossRef]

89. Harold, H. Economics of Exhaustible Resources; Edward Elgar Publishing: Cheltenham, UK, 1931; pp. 281-312.

90. Romerio, F.; Ferraz, C. Security of Supply and Renewable Energy in the Light of The Opening of Electricity Markets to Competition. In Proceedings of the Investing for Sustainability-5th SESSA Conference, Madrid, Spain, 19-20 May 2005.

91. Stefanova, B. European Strategies for Energy Security in the Natural Gas Market. J. Strat.Secur. $2012,5,7$. [CrossRef]

92. Gao, D.; Li, Z.; Liu, P. A coordinated energy security model taking strategic petroleum reserve and alternative fuels into consideration. Energy 2018, 145, 171-181. [CrossRef]

93. Li, P.; Zhang, J.S.; Xu, J.; Wang, P. A Dynamic Approach to Measuring China's Provincial Energy Supply Security along "the Belt and Road". Math. Probl. Eng. 2018, 2018, 16. [CrossRef]

94. Yao, L.; Chang, Y. Energy security in China: A quantitative analysis and policy implications. Energy Policy 2014, 67, 595-604. [CrossRef]

95. Wirl, F. The exploitation of fossil fuels under the threat of global warming and carbon taxes: A dynamic game approach. Environ. Resour. Econ. 1995, 5, 333-352. [CrossRef]

96. Generaldirektion Energie und Verkehr Europäische Kommission. Green Paper: Towards a European Strategy for the Security of Energy Supply; Office for Official Publications of the European Communities: Luxembourg, Germany, 2001.

97. Lu, Y.; Nakicenovic, N.; Visbeck, M. Policy: Five priorities for the UN Sustainable Development Goals. Nature 2015, 520, 432-433. [CrossRef] [PubMed]

98. Harris, D.V.P. Mineral resource stocks and information. Handb. Nat. Resour. Energy Econ. 2006, 3, 1011-1076.

99. Dorian, J.P.; Franssen, H.T.; Simbeck, D.R. Global challenges in energy. Energy Policy 2006, 15, $1984-1991$. [CrossRef]

100. Turton, H.; Barreto, L. Long-term security of energy supply and climate change. Energy Policy 2006, 34, $2232-2250$. [CrossRef]

101. Singh, R.K.; Murty, H.R.; Gupta, S.K. An overview of sustainability assessment methodologies. Ecol. Indic. 2009, 9, 189-212. [CrossRef]

102. Jonsson, D.K.; Johansson, B.; Månsson, A. Energy security matters in the EU Energy Roadmap. Energy Strateg. Rev. 2015, 6, 48-56. [CrossRef] 
103. Geng, J.; Ji, Q. Multi-perspective analysis of China's energy supply security. Energy 2014, 64, 541-550. [CrossRef]

104. Vivoda, V. Evaluating energy security in the Asia-Pacific region: A novel methodological approach. Energy Policy 2010, 38, 5258-5263. [CrossRef]

105. Lucas, J.N.V.; Francés, G.E.; González, E.S.M. Energy security and renewable energy deployment in the EU: Liaisons Dangereuses or Virtuous Circle? Renew. Sustain. Energy Rev. 2016, 62, 1032-1046. [CrossRef]

106. Matsumoto, K.; Shiraki, H. Energy security performance in Japan under different socioeconomic and energy conditions. Renew. Sustain. Energy Rev. 2018, 90, 391-401. [CrossRef]

107. Li, Y.; Shi, X.; Yao, L. Evaluating energy security of resource-poor economies: A modified principle component analysis approach. Energy Econ. 2016, 58, 211-221. [CrossRef]

108. Ren, J.; Sovacool, B.K. Quantifying, measuring, and strategizing energy security: Determining the most meaningful dimensions and metrics. Energy 2014, 76, 838-849. [CrossRef]

109. Mohsin, M.; Zhou, P.; Iqbal, N. Assessing oil supply security of South Asia. Energy 2018, 155, $438-447$. [CrossRef]

110. Månsson, A.; Johansson, B.; Nilsson, L.J. Assessing energy security: An overview of commonly used methodologies. Energy 2014, 73, 1-14. [CrossRef]

111. Brown, M.A.; Wang, Y.; Sovacool, B.K. Forty years of energy security trends: A comparative assessment of 22 industrialized countries. Energy Res. Soc. Sci. 2014, 4, 64-77. [CrossRef]

112. Ding, L.; Shao, Z.; Zhang, H. A Comprehensive Evaluation of Urban Sustainable Development in China Based on the TOPSIS-Entropy Method. Sustainability 2016, 8, 746. [CrossRef]

113. Von Hippel, D.; Suzuki, T.; Williams, J.H. Energy security and sustainability in Northeast Asia. Energy Policy 2011, 39, 6719-6730. [CrossRef]

114. Von Hippel, D.; Savage, T.; Hayes, P. Introduction to the Asian Energy Security project: Project organization and methodologies. Energy Policy 2011, 39, 6712-6718. [CrossRef]

115. Zhang, X.; Ruoshui, W.; Molin, H. A study of the role played by renewable energies in China's sustainable energy supply. Energy 2010, 35, 4392-4399. [CrossRef]

116. Augutis, J.; Krikštolaitis, R.; Pečiulytè, S. Dynamic model based on Bayesian method for energy security assessment. Energy Convers. Manag. 2015, 101, 66-72. [CrossRef]

117. Erahman, Q.F.; Purwanto, W.W.; Sudibandriyo, M.; Hidayatno, A. An assessment of Indonesia's energy security index and comparison with seventy countries. Energy 2016, 111, 364-376. [CrossRef]

118. Narula, K.; Sudhakara, R.B.; Pachauri, S. Sustainable energy security for India: An assessment of the energy supply sub-system. Energy Policy 2017, 103, 127-144. [CrossRef]

119. Wang, J.; Jing, Y.; Zhang, C. Review on multi-criteria decision analysis aid in sustainable energy decision-making. Renew. Sustain. Energy Rev. 2009, 13, 2263-2278. [CrossRef]

120. Zhou, P.; Ang, B.W.; Poh, K.L. Comparing aggregating methods for constructing the composite environmental index: An objective measure. Ecol. Econ. 2006, 59, 305-311. [CrossRef]

121. Cohen, G.; Joutz, F.; Loungani, P. Measuring energy security: Trends in the diversification of oil and natural gas supplies. Energy Policy 2011, 39, 4860-4869. [CrossRef]

122. Liu, F.; Zhao, S.; Weng, M. Fire risk assessment for large-scale commercial buildings based on structure entropy weight method. Saf. Sci. 2017, 94, 26-40. [CrossRef]

123. Beaumont, C. Forecasting: Methods and Applications. J. Oper. Res. Soc. 1984, 35, 79. [CrossRef]

124. Laviola, J.J. An Experiment Comparing Double Exponential Smoothing and Kalman Filter-Based Predictive Tracking Algorithms; IEEE Virtual Reality; IEEE Computer Society: Washington, DC, USA, 2003.

125. Jinliang, Z.; Yi-Ming, W.; Dezhi, L. Short term electricity load forecasting using a hybrid model. Energy 2018, 158, 774-781.

126. Xiao, L.; Wang, J.; Dong, Y. Combined forecasting models for wind energy forecasting: A case study in China. Renew. Sustain. Energy Rev. 2015, 44, 271-288. [CrossRef]

127. Wind Database of China. Available online: www.wind.com.cn (accessed on 3 June 2018).

128. National Bureau of Statistics of the People's Republic of China. Available online: http://www.stats.gov.cn/ (accessed on 18 June 2018).

129. Yao, L.; Chang, Y. Shaping China's energy security: The impact of domestic reforms. Energy Policy 2015, 77, 131-139. [CrossRef]

130. Fuller, W.A. Introduction to Statistical Time Series; John Wiley \& Sons: New York, NY, USA, 2009. 
131. Teresaledwina. Data-Driven Version of Neyman's Smooth Test of Fit. Publ. Am. Stat. Assoc. 1994, 427, 1000-1005.

132. Ledwina, T. Consistency and Monte Carlo Simulation of a Data Driven Version of Smooth Goodness-of-Fit Tests. Ann. Stat. 1995, 5, 1594-1608.

133. Inglot, T.; Ledwina, T. Asymptotic Optimality of Data-Driven Neyman's Tests for Uniformity. Ann. Stat. 1996, 5, 1982-2019.

134. Chalvatzis, K.J.; Ioannidis, A. Energy supply security in the EU: Benchmarking diversity and dependence of primary energy. Appl. Energy 2017, 207, 465-476. [CrossRef]

135. Lin, B.; Ouyang, X. A revisit of fossil-fuel subsidies in China: Challenges and opportunities for energy price reform. Energy Convers. Manang. 2014, 82, 124-134. [CrossRef]

136. Yuan, X.; Sun, X.; Zhao, W. Forecasting China's regional energy demand by 2030: A Bayesian approach. Resour. Conserv. Recycl. 2017, 127, 85-95. [CrossRef]

137. Matsumoto, K.; Andriosopoulos, K. Energy security in East Asia under climate mitigation scenarios in the 21st century. Omega 2016, 59, 60-71. [CrossRef]

138. Sovacool, B.K. Energy policymaking in Denmark: Implications for global energy security and sustainability. Energy Policy 2013, 61, 829-839. [CrossRef]

(C) 2019 by the authors. Licensee MDPI, Basel, Switzerland. This article is an open access article distributed under the terms and conditions of the Creative Commons Attribution (CC BY) license (http:/ / creativecommons.org/licenses/by/4.0/). 